\title{
O PERIODISMO JURÍDICO BRASILEIRO DO SÉCULO XIX
}

\author{
BRAZILIAN LAW REVIEWS IN THE XIX ${ }^{\text {TH }}$ CENTURY
}

DOI: 10.5533/1984-2503-20102304

Henrique Cesar Monteiro Barahona Ramos

\section{RESUMO}

O presente trabalho visa apresentar o estudo do periodismo jurídico no Brasil no Oitocentos, tomando as revistas jurídicas especializadas em direito não apenas como fonte, mas principalmente como objeto da pesquisa acadêmica, constituindo uma importante ferramenta para a análise da história das idéias jurídicas do Brasil no século XIX.

Palavras-chave: Periodismo, história das idéias jurídicas, história do direito.

\section{RESUMEN}

El presente trabajo pretende presentar el estudio del periodismo jurídico en Brasil en los Ochocientos, considerando las revistas jurídicas especializadas en derecho no solamente como fuentes, pero sobre todo como objeto de investigación académica, constituyendo una importante herramienta para el análisis de la historia de las ideas jurídicas de Brasil en el siglo XIX.

Palabras-clave: Periodismo, historia de las ideas jurídicas, historia del derecho.

\section{ABSTRACT}

The present article aims to present the study of different legal aspects in Brazil in the nineteenth century, using specialized law magazines not only as resource, but mainly 
as the object of the academic research, constituting an important tool in the analysis of the history of legal ideas in Brazil in the XIX century.

Key-words: law reviews, history of legal ideas, history of law.

\section{RÉSUMÉ}

La présent article vise à présenter une étude sur la recherche juridique au Brésil au dixneuvième siècle, en utilisant non seulement les revues juridiques spécialisées en droit comme sources, mais aussi comme objet de recherche universitaire constituant un outil important pour l'analyse de l'histoire des idées juridiques du Brésil au dix-neuvième siècle.

Mots-clés : revues juridiques - histoire des idées juridiques - histoire du droit

\section{1 - 0 Periodismo Jurídico e a Pesquisa Acadêmica no Campo do Direito:} Algumas Notas Introdutórias.

A consolidação da história social nas últimas três décadas do século $X X$ engendrou uma busca por novos objetos, fontes, teorias e metodologias de pesquisa acadêmica, refletindo diretamente noutras áreas do conhecimento das chamadas "humanidades". Com efeito, a história enquanto uma ciência não tem um objeto de estudo que seja exclusivamente seu; ela tem que dividi-lo com todas as ciências sociais e humanas com as quais se relaciona ${ }^{1}$, abrindo, desse modo, importantes perspectivas para o estudo da história das idéias jurídicas, fornecendo um amplo espectro de dados para um enfoque multidisciplinar neste campo de estudo.

Dentre os inúmeros objetos, fontes e métodos ainda por serem trazidos à lume na investigação da história das idéias jurídicas no Brasil, o presente ensaio tratará do periodismo jurídico brasileiro do Século XIX, também denominado jornalismo especializado ou jurídico, que até então permaneceu inexplorado pela pesquisa acadêmica em nosso país. Ou seja, o estudo do periodismo jurídico brasileiro

\footnotetext{
${ }^{1}$ Koselleck, Reinhart. (2006). Futuro Passado: contribuição à semântica dos tempos históricos, Rio de Janeiro: Contraponto: Ed. PUC-Rio, p. 120.
} 
Oitocentista, como objeto primeiro da pesquisa científica no campo do direito, ainda está por ser feito.

Não digo com isso que o periodismo jurídico já não tivesse sido indiretamente tomado como fonte de pesquisa, o que seria invariavelmente incorreto. Apenas à guisa de exemplo, aqui no Brasil, o estudo de Gizlene Neder sobre a construção da ordem burguesa no Brasil e sua correlação no discurso jurídico no Século XIX, tendo como objeto a utilização da mão-de-obra na transição para o capitalismo, com "destaque às representações chaves no discurso jurídico tais como crime, criminoso, contravenção, contraventor, delito, delinqüente" ${ }^{2}$, se debruçou sobre diversos dados encartados em periódicos jurídicos brasileiros daquela época. Eduardo Spiller Pena foi outro que examinou extensamente o discurso jurídico que dava ampla sustentação da ordem escravista no império, dentro daquele que seria o mais importante berço da intelectualidade brasileira no período final da escravidão, o Instituto da Ordem dos Advogados Brasileiros (IAB); também tendo como fonte de pesquisa diversos periódicos jurídicos do Oitocentos ${ }^{3}$. Também a título de exemplificação, já que o rol de autores aqui mencionado de forma alguma esgota o sem número de pesquisadores que utilizaram fontes seriadas do direito do Oitocentos, citamos o trabalho de Lilia Moritz Schwarcz sobre a presença das doutrinas cientificistas de cunho discriminatório nas Faculdades de Direito do Recife e de São Paulo, no qual foi pesquisado o material retirado das revistas jurídicas das duas mencionadas instituições de ensino jurídico brasileiras ${ }^{4}$.

Porém, apesar destes e de tantos outros trabalhos acadêmicos terem sido realizados a partir do exame das revistas especializadas como fonte bibliográfica de pesquisa, arrisco-me a dizer, permanece no Brasil um campo inexplorado da pesquisa científica sobre o jornalismo jurídico do Oitocentos considerado como um todo, e também sobre cada revista tomada individualmente, enquanto objeto ou tema primordial a ser enfrentado.

\footnotetext{
${ }^{2}$ Neder, Gizlene. (1995). Discurso Jurídico e Ordem Burguesa no Brasil, Porto Alegre: Sergio Antonio Fabris Editor, p. 23.

${ }^{3}$ Pena, Eduardo Spiller. (2005). Pajens da Casa Imperial, Campinas: Editora Unicamp, pp. 375-376.

${ }^{4}$ Schwarcz, Lilia Moritz. (2005). O Espetáculo das Raças: Cientistas, Instituições e a Questão Racial no Brasil 1870-1930, São Paulo: Companhia das Letras, p. 271.
} 
Um dos trabalhos pioneiros nesta fonte documental seriada de pesquisa acadêmica nos domínios do direito, se deve a Guilherme Braga da Cruz, em Portugal, a quem foi encomendada, em 1968, uma sucinta resenha histórica sobre a "Revista de Legislação e de Jurisprudência", destinada a ocupar algumas páginas do volume comemorativo do centenário desta mesma revista. No entanto, o que se produziu foi um estudo um pouco mais profundo, referente à própria história da "Revista", até então o mais completo trabalho sobre o periodismo jurídico em Portugal, denominado "A Revista de Legislação e Jurisprudência no Quadro do Periodismo Jurídico Português do Séc. XIX", que acabou por se estender em diversos volumes publicados. De tão interessante, pensou Braga da Cruz em dedicar-Ihe um estudo mais aprofundado, um desejo que somente foi interrompido pelo seu falecimento. No mesmo ano em que se comemorava o centenário da "Revista de Legislação e de Jurisprudência", tarefa semelhante àquela encomendada a Guilherme Braga da Cruz foi colocada nas mãos de Marcello Caetano, desta vez, para o centenário da revista "O Direito", que tomou aquele primeiro trabalho como referência.

Em 1983, reconhecendo a importância e riqueza do material encartado nos jornais jurídicos, Paolo Grossi organizou o Primeiro Encontro sobre "La 'Cultura' delle Reviste Giuridiche Italiane", realizado em Florença, marcando de uma vez por todas a redescoberta da literatura periódica jurídica do Oitocentos ${ }^{5}$. Na França, André-Jean Arnaud foi o responsável pela coordenação dos estudos intitulados "La Culture des Revues Juridiques Françaises", publicados em $1988^{6}$.

O marco fundamental dos estudos da imprensa jurídica na América Latina foi o seminário reunido em Buenos Aires, em 1994, por iniciativa de Victor Tau Anzoategui, sobre "As revistas jurídicas espanholas e argentinas (1850-1950)". As atas deste seminário foram publicadas também em Buenos Aires, em 1997, sob o título "La Revista Jurídica em la Cultura Contemporânea"7.

Em Portugal, Luis Bigotte Chorão transformou sua dissertação de Mestrado, defendida em 1997 na Faculdade de Direito da Universidade de Lisboa, no livro "O Periodismo Jurídico Português do Século XIX - Páginas de História da Cultura

\footnotetext{
${ }^{5}$ Chorão, Luís Bigotte. (2002). O Periodismo Jurídico Português do Século XIX - Páginas de História da Cultura Nacional Oitocentista, Lisboa: Imprensa Nacional/Casa da Moeda, p. 34

${ }^{6}$ Idem, p. 35
} 
Nacional Oitocentista", na qual abordou de forma bastante sintética o caso brasileiro, tornando-se um dos pioneiros no assunto. Armando Soares de Castro Formiga foi outro que também escreveu sua dissertação de Mestrado, desta vez na Faculdade de Direito da Universidade de Coimbra, no ano de $2002^{8}$, sobre a imprensa jurídica portuguesa e brasileira. Ambos não ultrapassaram os aspectos mais gerais do periodismo brasileiro do Segundo Reinado, limitando-se a citar alguns exemplos pontuais, direcionando o estudo ao caso português.

Bigotte Chorão sustenta a importância crescente do estudo do periodismo jurídico oitocentista, reconhecendo o seu valor documental e testemunhal ao mesmo tempo como objeto e fonte da história das idéias jurídicas e de outras áreas da investigação das ciências humanas.

\section{2 - O Periodismo Jurídico do Oitocentos.}

O movimento periodista no Brasil do Oitocentos está inserido num fenômeno de maior abrangência, que é história da imprensa no Brasil, ao que Nelson Werneck Sodré relaciona com a própria história do desenvolvimento da sociedade capitalista ${ }^{9}$. E, para compreendê-lo, é preciso recorrer à historicidade do jornalismo seriado na cultura ocidental como um todo.

O sociólogo polonês Zygmunt Bauman escreveu, nas últimas décadas do século $X X$, uma série de livros sobre a aceleração do tempo na modernidade e os efeitos desta nova experiência na subjetivação moderna. Em "O Mal-Estar da PósModernidade", livro que se tornou mundialmente famoso, cuja temática e o próprio título influenciaram diversos autores também aqui no Brasil ${ }^{10}$, Bauman retoma um texto de Sigmund Freud escrito em 1930, "O Mal-Estar na Civilização", no qual o pai da psicanálise aduz de um modo bastante original que "a escrita foi, em sua origem, a voz

\footnotetext{
${ }^{7}$ Idem, p. 11.

${ }^{8}$ Formiga, Armando Soares de Castro. "O Periodismo Jurídico em Portugal e no Brasil do Século XIX", disponível em www.geocities.com/armandoformiga/, acesso em 24.9.2008.

${ }^{9}$ Sodré, Nelson Werneck. (1966). A História da Imprensa no Brasil, Rio de Janeiro: Civilização Brasileira, p. 1.

${ }_{10}$ Birman, Joel. (2001). Mal-estar na atualidade, Rio de Janeiro: Civilização Brasileira; Serpa Junior, Octavio Dumont. (1998). Mal-estar na Natureza, Rio de Janeiro: Te Cora Editora.
} 
de uma pessoa ausente"11. A linguagem escrita, portanto, representava uma tecnologia pela qual uma pessoa ausente, à distância, transmitia uma informação qualquer.

O espaço e o tempo eram barreiras difíceis de serem transpostas, dificultando a circulação de informações e de idéias, até que o invento da imprensa possibilitou a reprodução mais rápida de textos, fazendo com que esta pessoa denominada "ausente" ficasse por sua vez cada vez mais próxima de um número cada vez maior de interlocutores pelo estreitamento do tempo. Esta nova dinâmica do tempo, a sua experiência pelos sujeitos históricos, talvez seja a marca que mais especialmente distinga a subjetivação moderna no processo de desenvolvimento do capitalismo. Como disse Félix Guatarri, "A ordem capitalista incide nos modos de temporalização".

Some-se ao incremento da imprensa o desenvolvimento também dos meios de transporte, e o resultado inevitável desta combinação foi que tempo e espaço passaram a se encurtar cada vez mais. Esta nova forma de informação foi importante na modernidade e interessava à crítica da civilização levada a termo por Freud:

"Reconhecemos, então, que os países atingiram um alto nível de civilização quando descobrimos neles tudo o que pode ajudar na exploração da Terra pelo homem e na sua proteção contra as forças da natureza - tudo, em suma, que é útil para ele - está disponível e é passível de ser conseguido",13.

Em seguida, Freud começa e enumerar uma série de avanços que indicam o quanto um país pode ser reconhecido como tendo atingido o mais alto grau civilizatório, deixando antever um deles em especial: "Os meios de comunicação são amplos, rápidos e dignos de confiança" ${ }^{14}$. O que é importante por ora destacar desta frase sobre a qual Bauman não se deteve na Introdução do seu livro - é o requisito ou qualidade de "rapidez" dos meios de comunicação utilizado pelo psicanalista para

\footnotetext{
${ }^{11}$ Freud, Sigmund. (1974). O Mal-estar na Civilização. Coleção Obras Completas, Rio de Janeiro: Imago Editora Ltda, p. 110.

${ }^{12}$ Guattari, Felix; Rolnik, Sueli. (1986). Micropolítica:Cartografias do Desejo, Petrópolis: Editora Vozes Ltda, p. 43.

${ }_{13}$ Freud, Sigmund, O Mal-estar na Civilização, op. cit., p. 112.

${ }^{14}$ Idem.
} 
identificar uma sociedade moderna, o que já há algum tempo vem sendo abordado também pelos historiadores na articulação entre poder, imprensa e historiografia ${ }^{15}$.

A conjugação entre tempo e imprensa como dispositivo de informação e de poder no seio da modernidade, será importante para a compreensão da ideologia jurídica oitocentista. $O$ próprio periodismo especializado surge em decorrência do intenso debate entre diversas concepções do direito, quer dizer, entre várias plataformas em processo de hegemonização que buscavam conferir, cada uma a seu modo, o estatuto moderno de validação da norma jurídica.

As idéias jurídicas daquela temporalidade, impulsionadas por uma elite que era porta-voz de si mesma, trabalhava com um determinado conjunto de "crenças" sobre o campo jurídico fundamentadas no paradigma legalista iluminista, como o da isenção da lei, da isenção do magistrado, o dogmatismo da norma etc., o que no início do século XIX se encontrava em pleno fogo cruzado. A propósito deste sistema de "crenças" encaminhado pelo pensamento jurídico ilustrado, Gizlene Neder nos informa que neste momento é que surge uma "crença na neutralidade e na igualdade jurídicas, crença sobretudo no papel desempenhado pela educação na ação disciplinadora da sociedade ${ }^{16 " .}$.

Esta função estratégica de angariar adesões para as diversas correntes jurídicas em contenda e colocar a informação em circulação de um modo cada vez mais atual, coube exatamente ao periodismo jurídico, que se constituiria, desde então, numa tecnologia riquíssima de poder. "Com o tempo de comunicação implodindo e encolhendo para a insignificância do instante, o espaço e os delimitadores de espaço deixam de importar" ${ }^{\prime 17}$.

No campo da história, Márcia Mansor D'alessio ${ }^{18}$, a partir dos trabalhos de Pierre Nora, trabalha com a idéia da aceleração do tempo na modernidade, e a sua rapidez cada vez maior nos meios de comunicação. Utilizando o paradigma que os sociólogos identificam como sendo a crise que se instaurou de forma paulatina nas práticas sociais, intelectuais e institucionais no final da Idade Média e início do Renascimento

\footnotetext{
${ }^{15}$ Ferreira, Antônio Celso (Org.). (2007). O Historiador e seu Tempo, São Paulo: Unesp, p. 129.

${ }^{16}$ Neder, Gizlene, (1995). Discurso Jurídico e Ordem Burguesa no Brasil, Porto Alegre: Sergio Antonio Fabris Ed., p. 119.

${ }^{17}$ Bauman, Zygmunt. (1999). Globalização, Rio de Janeiro: Jorge Zahar Ed., p. 20.
} 
na Europa, problematiza o engendramento de um novo tipo de sujeito - o da modernidade - constituído através de uma outra experiência do tempo.

Para Bauman, "a relação entre tempo e espaço deveria ser de agora em diante processual, mutável e dinâmica, não predeterminada e estagnada ${ }^{19 " .}$. Ainda a este propósito, Antony Giddens explica o fenômeno dizendo que "os modos de vida produzidos pela modernidade nos desvencilharam de todos os tipos tradicionais de ordem social, de uma maneira que não tem precedentes ${ }^{20 "}$. Segundo ele, até então "o tempo ainda estava conectado com o espaço (e o lugar) até que a uniformidade da mensuração do tempo pelo relógio mecânico correspondeu à uniformidade na organização social do tempo 21 ". Contudo, "o advento da modernidade arranca crescentemente o espaço do tempo fomentando relações entre outros 'ausentes', localmente distantes de qualquer situação dada ou interação face a face ${ }^{22 " . ~}$

Entretanto, além da alusão à rapidez dos meios de comunicação como sendo um atributo dos povos civilizados existente no pensamento freudiano, há um outro aspecto da modernidade que também nos interessa de maneira bastante especial para a análise do periodismo na imprensa do Oitocentos e sua relação com o liberalismo: a noção de "ordem" e seus desdobramentos na formação de uma ordem médica, ordem econômica, ordem jurídica, etc.

\section{3 - Uma Nova Ordem e o Novo Estatuto Jurídico da Modernidade.}

Sobre esta segunda peculiaridade da civilização, esta sim, abordada por Bauman da Introdução do livro de sua autoria já mencionado ${ }^{23}$, Freud chega mesmo a dizer que:

\footnotetext{
"A ordem é uma espécie de compulsão a ser repetida, compulsão que, ao se estabelecer um regulamento de uma vez por todas, decide quando, onde e como, uma coisa será efetuada, e isso de tal maneira que, em todas as circunstâncias semelhantes, a hesitação e a indecisão nos são poupadas. ${ }^{24}$
}

\footnotetext{
18 “Imprensa, história, historiografia: algumas observações”, In Ferreira, Antônio Celso (Org.). (2007). O Historiador e seu Tempo. Unesp, São Paulo, p. 129.

${ }_{19}$ Bauman, Zygmunt. (2001). Modernidade Líquida, Rio de Janeiro: Jorge Zahar Ed, p. 131.

${ }^{20}$ Giddens, Antony. (1991). As Conseqüências da Modernidade, São Paulo: Unesp, p. 14.

21 Idem, p. 26.

22 Idem, p. 27.

23 Bauman, Zygmunt . (1998). O Mal-Estar da Pós Modernidade, Rio de Janeiro: Jorge Zahar Ed, p. 7.

${ }^{24}$ Freud, Sigmund, O Mal-estar na Civilização, op. cit, p. 113.
} 
A relação entre velocidade e "ordem", ou entre tempo e lei, é uma temática típica da modernidade, e foi explicitada de forma clara pela primeira vez por Freud, para quem "Os benefícios da ordem são incontestáveis. Ela capacita os homens a utilizarem o espaço e o tempo para seu melhor proveito, conservando ao mesmo tempo as forças psíquicas $^{25 " \text {. }}$

Foi no final do século XVIII que a contestação do modelo de organização do Antigo Regime, esquematizado segundo a visão de mundo pela qual as leis seriam emanações divinas que ordenavam (de "ordem") todo o universo, encontrou a sua culminância, sucumbindo à "razão" como fundamento de validade de toda conduta humana. Paulatinamente, o homem passou a figurar no centro de emanação da lei, que deixava de ser um atributo divino para constituir uma virtude do cidadão, expressão máxima do gozo das liberdades civis e políticas em face à opressão Absolutista. A perfectibilidade divinal da lei que era ensinada nas universidades européias até o final do século XVIII, e que servia de ossatura para as instituições do Antigo Regime, entrou, dali em diante, em confronto com outras formas de pensar e sentir o fenômeno jurídico, secularizando a lei e plasmando a noção de norma sob a égide da razão. E enquanto as diversas correntes de pensamento de digladiavam, era preciso arregimentar cada vez mais adeptos e educar o vulgo, e isso nos lugares mais longínquos, de maneira cada vez mais rápida.

O contratualismo, síntese metafórica da modernidade, transformou o súdito em cidadão, conferindo a este último, através da sua vontade individual e livre, a primazia de ser o único senhor de si. Toda a noção de "ordem", esta verdadeira obsessão moderna, seria submetida à razão e expressa teoricamente numa lei a ser observada por todos os signatários do contrato social. Assim, como nos diz Lucia Maria Bastos P. Neves, "os tradicionais valores sociais e políticos do Antigo Regime, ainda em vigor na maioria das monarquias européias, especialmente no mundo ibérico, passavam a ser contestados. A Europa secularizava-se"26.

\footnotetext{
${ }^{25}$ Idem.

${ }^{26}$ Peixoto, Antônio Carlos, et al. (2001). O Liberalismo no Brasil Imperial. Rio de Janeiro: Revan/UERJ, p. 74.
} 
O choque entre as duas visões de mundo, uma fundada no arraigado arbítrio de uma realeza coroada de poderes outorgados por Deus, e uma outra que trazia uma nova "ordem" tingida com as cores da liberdade, igualdade e fraternidade, ocorreu nos dois lados do Atlântico quase simultaneamente: nos Estados Unidos, em 1776, e na França, em 1789. E foi justamente no ambiente político pré-revolucionário francês do século XVIII, de crucial importância para o incremento do capitalismo mundial, que teve origem o movimento periodista do direito na Europa, acompanhando o crescimento tecnológico da própria imprensa em geral.

Neste período, assistiu-se à emergência do jornalismo como um todo, favorecido por alguns fatores importantes, tais como a liberdade de expressão e de opinião, o incremento da tecnologia e a complexificação sócio-econômica daquela época. E, ao nível do sujeito, a subjetivação moderna sendo moldada pelo capitalismo nascente a acelerar-se cada vez mais rapidamente. A partir da conjugação destes elementos, o que se viu foi o aparecimento do periodismo segmentado, em especial nas áreas renovadas das ciências, medicina e engenharia, implementando notadamente uma tecnologia de propagação e reprodução de idéias de cunho intelectual, cultural e científico, numa amplitude e rapidez jamais experimentadas até então. A relação actualidade-periodicidade é assim entendida e observada por Rui de Figueiredo Marcos:

\begin{abstract}
"O berço oitocentista do periodismo jurídico encontra explicação no quadro de um frenesim de entusiástica reformação legislativa que soprou da Europa e varreu o nosso país. Na nova óptica do jurista do Século XIX, o tempo passou a medir-se em termos mais curtos e exigentes. Defronte de um legislador tomado de vertigem empreendedora, o jurista tornou-se ansioso e sôfrego de informações precisas e actuais. Ora, a essência das publicações, o seu préstimo mais nobre naquele ambiente histórico, não resistiu na periodicidade, mas sim na actualidade. De maneira que, implacavelmente, quanto menor fosse o intervalo de periodicidade, maior seria a garantia de actualidade,27.
\end{abstract}

Já na primeira metade do século XVIII, um advogado da Corte de Paris, Gayot de Pitaval, escreveu uma extensa obra composta de 18 volumes, denominada "Causes Celebres et Interessantes", compilando e comentando inúmeros julgados relativos às

\footnotetext{
${ }^{27}$ Marcos, Rui de Figueiredo. (2002). "A Fundação do Boletim da Faculdade de Direito e o Periodismo Jurídico em Coimbra", In Boletim da Faculdade de Direito, Coimbra, Apud Formiga, Armando Soares de
} 
mais variadas áreas do direito daquela temporalidade. O autor reclamava a necessidade de levar as causas até então restritas aos escritórios dos advogados a um número cada vez maior de leitores e de juristas. Assim o fazendo, cumpria uma dupla tarefa: ampliava o discurso jurídico para além do círculo seleto dos juristas, e também, no seio dos próprios juristas, favorecia a disputa entre as diversas correntes doutrinárias e jurisprudenciais ${ }^{28}$. Mas faltava-lhe o atributo da atualidade, o que apenas foi remediado com o periodismo jurídico.

As primeiras iniciativas do jornalismo especializado em direito, portanto, remontam à França, onde surgiram, em 1773, o "Journal des Causes Celèbres" (percebam a similitude entre o título deste primeiro periódico e o da obra de Gayot de Pitaval) e, em 1786, a "Gazette des Tribunaux". Logo sem seguida surgiu a "Jurisprudence de la Cour de Cassation", iniciada em 1791, e o "Journal des Notaires et le Avocats", fundado em 1808.

Mas apesar de ter surgido na França no final do Século XVIII, o movimento se consolidou com toda a sua força somente na primeira metade do Oitocentos, principalmente na Alemanha, a partir da publicação em 1815, do jornal especializado "Zeitschrif für geschichitliche Rechtwissenschalft", editado por Friedrich Carl von Savigny. Seguiram-no as revistas "Archiv der Gesellschaft für aeltere deutsche Geschichtskunde, de 1820, e Zeitschrift für deutsches Recht”, de 1839.

Como característica própria, o impulso do jornalismo jurídico da Alemanha foi marcado pela correlação de forças entre a escola histórica do direito, capitaneada por Savigny, e a jusnaturalista. Este importante jurista viu no periodismo a possibilidade de propagar periodicamente textos com ares de atualidade, que abordassem 0 pensamento jurídico-doutrinário das duas escolas em contenda, se prestando a defender ou combater o constitucionalismo liberal, a divulgação da jurisprudência; dar

Castro. "O Periodismo Jurídico em Portugal e no Brasil do Século XIX", disponível em www.geocities.com/armandoformiga/, acesso em 24.9.2008, p. 5.

${ }^{28}$ Pitaval, Gayot de. (1746). Causes Celebres et Interessants. Haye: Chez Jean Neaulme. Tome Septime, p. III. Eis o trecho na íntegra: "Quand j'ai volu donner au Public um choix exquis de Causes qui pussent exciter sa curiosité, une foule d'Arretistes s'est présentée à moi, presque tous hérisses des épines du Barreau, relégués dans les Cabinets des Avocats, ou des Plaideurs de profession, qui n'ont jamais entrepris de les lire d'um bout à l'autre, \& qui ne les consultent que dans um besoin pressant. Le sort de ces Auteurs ne m'a point tente: j'ai eu l'ambition d'avoir une Cour nombreuse des Lectrices, dûssa-je avoir bien des Critiques; car tant pis pour l'Ouvrage dont on ne dit rien, c'est à coup sûr un Livre qui moisit chez le Libraire". 
publicidade às leis e aos códigos, criticar as decisões judiciais, dialogar com velhas e novas teorias. Este era o espírito dos primeiros periódicos destinados ao mundo jurídico oitocentista e que se vulgarizou para o restante do mundo. Uma linguagem nova, distinta do jornalismo político disponível até então, mas que se encaixava perfeitamente numa idéia de sistematização interna do próprio direito perseguida por Savigny em duas obras.

O jornalismo especializado surgiu na Itália em 1816, com a publicação da "Raccolta delle più importanti decisioni dei supremi tribunali di Roma in materia contenziosa", e no ano seguinte com o "Repertorio generali di giurisprudenza dei tribunali romani per l'anno...", compilado por Luigi Cecconi. Seguiram-nas o "Diario Forense Universale", de 1823, e os "Annali di giurisprudenza", de 1839.

Da Espanha se tem notícia da revista "Gaceta de los Tribunales", editada em maio de 1834. No mesmo ano, a 17 de agosto, foi publicado o primeiro volume dos "Anales Administrativos", atribuído a Joaquim Francisco Pacheco. Foi este último quem também redigiu, junto com Pascual Fernández Baeza e Hernández de La Rua, o "Boletin de Jurisprudencia y Legislación", e ainda o diretor da "Cronica Jurídica", publicada em 1839.

Entre 1843 e 1845, o "Colegio de Abogados de Madrid" contou com uma revista oficial, denominada "La Universidad y El Foro". Posteriormente, o "Colegio" continuou a publicação de "El Derecho Moderno", surgida em 1853, sob a direção de Ignacio Miquel y Rubert e José Reus.

A imprensa jurídica teve início em Portugal em meio aos desdobramentos do vintismo, uma experiência que muito nos interessa, pelo tronco comum que representou em grande parte com a realidade brasileira nas duas primeiras décadas do Oitocentos. Foi após este período de grande turbulência política, e nas sucessivas idas e vindas, em que "os canhões e o verbo secundarizaram a cultura técnica e científica" ${ }^{29}$, que paulatinamente se abriu o caminho para as aspirações de ascenção e queda do primeiro liberalismo português, no seio da qual os juristas buscavam um modelo de organização e intevenção preponderante. Um debate que se refletia nas duas margens atlânticas do império luso-brasileiro, como veremos mais adiante.

\footnotetext{
${ }^{29}$ Chorão, Luis Bigotte, O Periodismo Jurídico, op. cit, p. 48.
} 
É justamente neste contexto liberal que se deve compreender o surgimento da imprensa jurídica em Portugal, impulsionada pela Sociedade Jurídica de Lisboa, com a publicação dos "Anaes da Sociedade Jurídica", em 1835. Logo de início se percebe o triunfo das idéias liberais em Portugal após a revolta constitucionalista, ao lermos no prólogo que

"uma das cousas que mais tem concorrido para a civilização dos Povos, e para a prosperidade dos Estados (...) planta que cresce, e frutifica copiosamente no solo abençoado dos Governos Livres, e que mui raras vezes vegeta no solo açoutado pelo vento esterilizador do despotismo,30.

A luta ideológica que embaralhava direito e política seria travada agora também nas páginas de revistas especializadas dos periódicos de direito. Segundo Luis Bigotte Chorão, que fez do periodismo jurídico português do Século XIX objeto de sua Dissertação de Mestrado em Ciências Histórico-Jurídicas pela Faculdade de Direito de Lisboa, defendida em 1997:

\begin{abstract}
"A história dos primeiros jornais jurídicos portugueses não pode dissociar-se da história das instituições que os originaram, e correspondem essencialmente às pretensões associativas dos juristas os quais, em nome de um saber próprio, reivindicaram o reconhecimento de uma missão específica, obtido em momentos diferentes, sempre em termos expressivos por parte dos poderes públicos.

Se num primeiro momento a questão essencial girou em torno da escolha de um modelo organizativo e de intervenção dos juristas, e não só dos advogados, tendo sido inclusivamente submetida à discussão na Sociedade Jurídica de Lisboa a proposta da sua fusão com todas as outras Sociedades existentes em Lisboa, comprehendendo a Academia Real das Sciências (...) para formarem uma Sociedade Geral, intitulada = Sociedade dos Amigos da Instrucção, e do Bem Público de Portugal', numa segunda fase são os advogados, entre os juristas, quem toma a dianteira no plano associativo,31.
\end{abstract}

No ano seguinte, surge através da Sociedade Jurídica do Porto, a "Revista Jurídica". Seguiram-na a "Gazeta da Relação de Lisboa" (1838), o "Boletin dos Tribunaes" (1838) e a "Chronica Jurídica" (1840), primeiro jornal da Universidade de Coimbra. Em 1841 foram publicadas a "Gazeta dos Tribunaes", levada a efeito pela Associação dos Advogados de Lisboa e a "Revista dos Tribunaes", dirigida por Francisco Gouveia Pimenta.

\footnotetext{
${ }^{30}$ Apud Chorão, Luis Bigotte, O Periodismo Jurídico, op. cit, p. 63.
} 
Já na segunda metade do Século XIX, aparece em 1851 o jornal "O Direito", com o propósito de dar "notícia biographica dos principaes jurisconsultos nacionaes e estrangeiros"32, evidenciando a circulação das idéias jurídicas pelo jornalismo especializado lusitano chegadas de todo o continente.

Da Imprensa da Universidade de Coimbra sai em 1856 a "Revista Jurídica", mantendo os seus redatores anônimos sob as iniciais "RR.". O programa desta revista fazia um curioso diagnóstico da conjuntura jurídica e estabelecia as seguintes diretrizes:

“(...) reunir no mesmo quadro o exame dos princípio de direito, a sua applicação, de todos os dias, e que ajude a dirigir a práctica da legislação em harmonia com os verdadeiros princípios (...) serviço valioso tanto mais necessário, quanto na actualidade o estado da nossa legislação é cahotico e a práctica incerta. As decisões das Relações e do Supremo Tribunal de Justiça a cada passo appresentam direito novo; ou antes muitas vezes fazem uma applicação nova dos princípios de direito, que quase se confundem com esta nova espécie de jurisprudências",33.

Ao todo foram 51 revistas jurídicas portuguesas relacionadas por Luis Bigotte Chorão ao longo da interessante pesquisa que ele realizou a respeito da imprensa seriada de direito oitocentista em Portugal, embora sem destacar o aspecto político de tais revistas especializadas.

A importância do movimento tal como se deu em Portugal nos interessa pela repercussão que teve no periodismo brasileiro do Oitocentos, sobretudo como conseqüência dos acontecimentos que sucederam à Revolução Constitucionalista do Porto.

\section{4 - O Periodismo Político Brasileiro Oitocentista.}

A análise do surgimento do periodismo especializado no Brasil no século XIX não pode prescindir da conjunção de três aspectos fundamentais, profundamente imbricados entre si, que foram o próprio desenvolvimento material da imprensa como um todo em solo brasileiro, a circulação das idéias a partir da matriz do liberalismo luso-brasileiro das primeiras duas décadas do Oitocentos, e o papel dos juristas como

\footnotetext{
${ }^{31}$ Chorão, Luis Bigotte, O Periodismo Jurídico, op. cit, p. 49.

${ }^{32}$ Apud Chorão, Luis Bigotte, O Periodismo Jurídico, op. cit, p. 129.
} 
principais protagonistas destas idéias, desempenhando o papel decisivo de tecnólogos da imprensa. Eram os juristas que desde os bancos acadêmicos exercitavam a retórica ao entregarem-se apaixonadamente ao jornalismo, fenômeno que apenas perdeu fôlego depois de proclamada a República ${ }^{34}$.

As origens do periodismo jurídico no periodismo comum marca uma certa descontinuidade histórica, sendo o papel do pesquisador cotejar as distinções entre um e outro, bem como seus eventuais pontos de interseção. No entanto, é um fato inolvidável que esta diferenciação possui uma historicidade. O público de jurisconsultos se apresenta mais seleto e específico, o linguajar utilizado é mais técnico e erudito, e a cientificidade da disciplina jurídica não se dá a conhecer a todo à generalidade dos leitores, não devendo ser vertida sob a forma direta e irônica com que apareciam comumente até então nos folhetins, pasquins e revistas. Nem tampouco a política poderia aparecer entrincheirada como nos órgãos oficiais dos partidos políticos imperiais, senão com o verniz da retórica jurídica, habilmente manipulada pelos homens de beca. Mas não se pode negar que os agentes que faziam a imprensa eram os mesmos que faziam a lei e encaminhavam as discussões políticas. Sobre a relação entre o direito, a política e o jornalismo, Silvio Romero dizia que "No Brasil, mais ainda do que noutros países, a literatura conduz ao jornalismo e este à política que, no regime parlamentar e até no simplesmente representativo, exige que seus adeptos sejam oradores ${ }^{35}$ ". Por isso vamos encontrar nas páginas dos periódicos jurídicos os nomes dos maiores juristas nacionais daquela temporalidade, como Antônio Rebouças, Teixeira de Freitas, Coelho Rodrigues, Lafayette Rodrigues Pereira, Tobias Barreto, Ruy Barbosa, Clóvis Beviláqua, Carvalho de Mendonça, Macedo Soares, dentre tantos outros.

O discurso jurídico possui matizes diferenciados, propriedades técnicas particulares, mas pode também ser compreendido de forma mais aberta, contendo "formas difusas e dispersas na formação ideológica, que encaminham algum tipo de reflexão com normas de legalidade ${ }^{36 ", ~ t a l ~ c o m o ~ c o n c e b i d o ~ p o r ~ G i z l e n e ~ N e d e r . ~ " A s s i m, ~}$ estamos alargando o conceito de discurso jurídico para além de uma categoria social

\footnotetext{
${ }^{33}$ Idem, p. 130-131.

${ }^{34}$ Ver a esse respeito Neder, Gizlene. Discurso Jurídico..., op. cit, p. 128 e 129.

${ }^{35}$ Apud Sodré, Nelson Werneck, A História da Imprensa no Brasil, op. cit, p. 212.
} 
específica, colocando em outros agentes históricos a possibilidade de pensar normativamente, inclusive sobre a legalidade ${ }^{37 "}$.

De qualquer modo, o altíssimo índice de analfabetismo e a concentração dos postos de poder em sua grande maioria nas mãos de intelectuais egressos das faculdades de Direito de Olinda e São Paulo, ressalvados alguns médicos, engenheiros, clérigos e funcionários públicos, fazia com que o grupo de leitores tanto da imprensa comum quanto a especializada fosse basicamente o mesmo. Deste modo, não se pode negar que os homens de imprensa eram também os homens de poder, isto é, faziam parte do "estamento burocrático" de que fala Raymundo Faoro ${ }^{38}$.

Há, todavia, mais um argumento fundamental: a especialização do discurso jurídico através da imprensa periódica jurídica, no bojo de toda a liberdade que esta gozava no Brasil, teve um caráter estratégico disciplinar. "As 'Luzes' que descobriram as liberdades inventaram também as disciplinas 39 ", como disse Foucault. Segundo ele, "as disciplinas são técnicas para assegurar a ordenação das multiplicidades humanas ${ }^{40 ",}$ do que podemos extrair dois aspectos importantes nesta breve introdução ao tema. O primeiro deles é a noção de "ordem" já antes aludida, tão cara ao liberalismo, dentro da qual os juristas se colocavam no topo da escala, na dianteira do processo de ideologização burguesa, vertido naquilo que se consolidaria mais tarde como "bacharelismo" no Brasil. O segundo aspecto, o das "multiplicidades humanas", é justamente aquele que o processo de homogeneização visava capturar ao dispor da tecnologia ou dispositivo da imprensa periódica, veiculando "modelos" de pensamento jurídico e espalhando-os por todo o Império. Veremos como isso se deu alguns parágrafos abaixo, quando tratarmos do engendramento da subjetivação burguesa ao encaminhar as reformas legislativas que ocorreram no Brasil a partir das décadas de 1840/50.

Passaremos, então, à investigação de como surgiu o movimento de imprensa periódica como um todo no Brasil, e compreender como a tradição de debates jurídicos na imprensa foi veículo das idéias políticas liberais radicais ou conservadoras, até o

\footnotetext{
${ }_{37}^{36}$ Neder, Gizlene. Discurso Jurídico..., op. cit, p. 12.

${ }^{37}$ lbidem.

${ }^{38}$ Faoro, Raymundo. (2001). Os Donos do Poder: formação do patronato político brasileiro, São Paulo: Globo, p. 557

${ }^{39}$ Foucault, Michel. (1993). Vigiar e Punir: história da violência nas prisões, Petrópolis: Vozes, p. 195.
} 
ano de 1843, quando surge o periodismo jurídico no Brasil, curiosamente no mesmo ano da criação do Instituto dos Advogados do Brasil (IAB). Tentaremos mostrar ainda que essa coincidência de datas não foi mero acaso.

A imprensa periódica no Brasil, de um modo geral, nasceu em 1808, com a "Gazeta do Rio de Janeiro", após a transferência da Corte de D. João VI para o Brasil, fugindo do cerco napoleônico em Lisboa. Antes disso, o rígido controle da metrópole sobre a difusão das idéias através do livro fazia com que este fosse visto como um "instrumento herético ${ }^{41 ",}$, somente admitido para os ofícios religiosos e mais nenhum. Mas isso não quer dizer que não havia livros e que, por este motivo, não havia a circulação das idéias. No final do século XVIII iniciou-se o comércio mesmo clandestino de livros considerados proibidos, e os autos da "Devassa" da conjuração mineira, por exemplo, não deixam dúvidas da existência de bibliotecas particulares, vistas pelas autoridades judiciárias como a prova cabal e incontestável da conspiração praticada pelos inconfidentes. Apenas a título de exemplo, o cônego Luiz Vieira tinha em seu poder Condillac, Montesquieu, Mably e a Enciclopédia; o alferes Tiradentes possuía um original em francês da "Coleção das Leis Constitucionais dos Estados Unidos da América". O mesmo aconteceu com Cipriano Barata e Muniz Barreto na Conjuração Baiana de 1798, e com Mariano José Pereira da Fonseca, futuro Marquês de Maricá, no Rio de Janeiro, que teve que jurar nunca ter lido os livros de Mably e Raynal que foram encontrados com ele. Ainda que proibidos, os livros ingressaram no Brasil do mesmo modo como as idéias liberais.

A primeira tentativa de instalação de uma tipografia no Brasil durante o período colonial ocorreu em 1706, quando surgiu no Recife uma tipografia para a impressão de letras de câmbio e orações devotas com a autorização do governador Francisco de Castro Morais. Imediatamente, a Carta Régia de 8 de junho do mesmo ano pôs fim à tentativa. Outro caso se deu no Rio de Janeiro, em 1746, com a transferência da metrópole de Antônio Isidoro da Fonseca, antigo impressor em Lisboa. A oficina chegou a imprimir a Relação da Entrada do bispo Antônio do Desterro, redigida por Luiz Antônio Rosado da Cunha, com dezessete páginas de texto. Mas a reação da Corte foi rápida, com a ordem régia de 6 de julho de 1747 determinando o seqüestro do

\footnotetext{
${ }^{40}$ Idem, p. 191.

${ }^{41}$ Sodré, Nelson Werneck, A História da Imprensa no Brasil, op. cit., p. 14.
} 
maquinário para o Reino para que "não imprimissem livros, obras ou papéis alguns avulsos (...), sob pena de que, fazendo o contrário, seriam remetidos presos para 0 Reino para se Ihes impor as penas em que tivessem incorrido ${ }^{42,}$.

A imprensa somente teria vez no Brasil quando, na partida da Corte para o Brasil em 1808, Antônio de Araújo, futuro conde da Barca, na confusão da fuga, mandou colocar no porão da Medusa o material gráfico que havia sido adquirido para a Secretaria de Estrangeiros e da Guerra, da qual era titular, e que sequer chegara a ser montado. Chegando na colônia, foi instalada nos baixos da sua casa, onde passou a funcionar sob o ato real de maio:

\begin{abstract}
"Tendo-me constado que os prelos que se acham nesta capital eram destinados a Secretaria de Estado dos Negócios Estrangeiros e da Guerra, e atendendo à necessidade que há de oficina de impressão nestes meus Estados, sou servido que a casa onde eles se estabeleceram sirva inteiramente de Impressão Régia, onde se imprimam exclusivamente toda a legislação e papéis diplomáticos, que emanarem de qualquer repartição do meu Real Serviço, ficando inteiramente pertencendo o seu governo e administração à mesma Secretaria. Dom Rodrigo de Souza Coutinho, do meu Conselho de Estado, ministro e secretário dos Negócios Estrangeiros e da Guerra, o tenha assim entendido, e procurará dar ao emprego da oficina a maior extensão e lhe dará todas as estações o que mais convier ao meu Real Serviço. Palácio do Rio de Janeiro, em 31 e maio de $1808^{, 43}$.
\end{abstract}

Foi assim que, em 10 de setembro de 1808, saiu do prelo o número inaugural do primeiro periódico no Brasil, a "Gazeta do Rio de Janeiro", em papel impresso de pouca qualidade, com quatro páginas in $4^{\circ}$, com assinatura semestral de $3 \$ 800$ ou 80 reis o número avulso, à venda na loja de Paul Martin Filho, dando notícia apenas do que se passava na Europa. Antes disso, havia surgido em Londres, no dia $1^{\circ}=$ de junho de 1808 o "Correio Brasiliense". Embora cronologicamente tivesse sido dado a prelo anteriormente à "Gazeta do Rio de Janeiro", não foi editado em terras brasileiras, não circulou por aqui senão clandestinamente, motivo pelo qual não pode ser considerado como o primeiro periódico lançado em território nacional. Seu fundador, Hipólito da Costa, justificou-se do seguinte modo: "Resolvi lançar esta publicação na capital

\footnotetext{
${ }^{42}$ Idem, p. 21.

${ }^{43}$ Idem, p. 22.
} 
inglesa dada a dificuldade de publicar obras periódicas no Brasil, já pela censura prévia, já pelos perigos a que os redatores se exporiam ${ }^{44 "}$.

Deixando de lado a discussão se o "Correio Brasiliense" foi o primeiro periódico brasileiro ou não, interessa para este ensaio observar que este jornal distinguia-se da "Gazeta" justamente pelo aspecto doutrinário do seu periodismo. Como salientou Nelson Werneck Sodré, o "Correio" "pretendia, declaradamente, pesar na opinião pública, ou o que dela existia no tempo, ao passo que a Gazeta não tinha em alta conta esta finalidade (...) O jornal de Hipólito, ao contrário, destinava-se a conquistar opiniões ${ }^{45}$." Mesmo devendo ser reconhecido que a "Gazeta do Rio de Janeiro" trazia em si também uma ideologia nas suas entrelinhas, foi decididamente com o "Correio Brasiliense" que o Brasil conheceu a propaganda de idéias de cunho liberal, preparando o terreno para o impulso das instituições liberais no país em oposição ao jugo daquelas ligadas ao Absolutismo lusitano.

Nos anos seguintes, vimos surgir na Bahia, em 1811, a oficina tipográfica de Manuel Antônio da Silva Serva, onde foram impressos o "Prospecto da Gazeta da Bahia e a Idade de Ouro do Brasil". No Recife, apareceu uma tipografia importada por Ricardo Rodrigues Catanho em 1815. Foi nela que os revoltosos de 1817 imprimiram no dia 28 de março o documento político conhecido como "Preciso", no qual José Luis Mendonça afirmava as bandeiras dos revolucionários e colocava o problema da liberdade no processo de independência. A bandeira revolucionária que vinculava ao nível das idéias as instituições reais portuguesas à "tirania" e "monstruosidade infernal" era assim expressa logo no seu primeiro parágrafo:

"PRECISO dos sucessos que tiveram lugar em Pernambuco, desde a faustíssima e gloriosíssima Revolução operada felizmente na Praça do Recife, aos seis do corrente mês de março, em que o generoso esforço de nossos bravos PATRIOTAS exterminou daquela parte do Brasil o monstro infernal da tirania real ${ }^{, 46}$.

Aqui já era possível perceber que as idéias e os acontecimentos do final do século XVIII e início do Oitocentos, constituíram o substrato da literatura jurídica e

\footnotetext{
${ }^{44}$ Idem, p. 24.

${ }^{45}$ Idem, p. 26.

${ }^{46}$ Idem, p. 43.
} 
política escrita nas décadas seguintes. Os ventos do liberalismo no império lusobrasileiro - os mesmos que sopraram na França pré-revolucionária e que impulsionaram o surgimento do periodismo jurídico no mundo - sacudiram as bases do centralismo administrativo que a coroa portuguesa impunha ao espaço colonial brasileiro desde a segunda metade do século XVIII. Palavras como "revolução", "democracia" e "república" passaram a fazer parte do vocabulário político dos homens do início do século XIX, tanto na metrópole quanto na colônia.

Até o ano de 1815 a situação da corte de $\mathrm{D}$. João era relativamente tranqüila no Brasil, estando o ambiente político português tomado pelas repercussões da invasão napoleônica, e com o protecionismo inglês sob a batuta do marechal John Beresford, que se refletia na completa ingerência dos assuntos políticos na metrópole a pretexto de assuntos diplomáticos. Todavia, a queda de Napoleão deixou um "vácuo" político que propiciou as discussões a respeito do retorno do rei para a península, e das bases do modelo monárquico, ou seja, a recomposição da elite política portuguesa agora sob o influxo das idéias liberais, sinônimo naquele instante de unidade e independência. Afinal de contas, Portugal seguia as ordens que vinham de uma distância de 2 mil léguas, ditadas pelos interesses britânicos, numa inversão de papéis entre metrópole e colônia que desagradava sobremaneira a essa elite.

Já em 1817, ocorrera uma frustrada tentativa de aclamação de D. João como rei constitucional, organizada pela maçonaria portuguesa, visando não somente a volta do monarca, mas a total independência do jugo inglês. Este modelo conspiratório secreto deu origem ao chamado "Sinédrio", fundado na cidade do Porto no ano seguinte, tendo à frente Manuel Fernandes Tomás, também com a finalidade de se implantar a revolução liberal no país. O modelo constitucionalista ganharia mais e mais força nesses meios, angariando adesões de vários setores da sociedade lusitana em virtude das dificuldades econômicas que se sucederam à guerra. Em 1820 o "Sinédrio" detinha um considerável dispositivo militar, colocando-se em desentendimento com o marechal Beresford.

Tendo que optar entre as idéias do governador português Miguel Ferreira Forjaz, ligado aos interesses liberais, e as do marechal Beresford, que havia atravessado o Atlântico para fazer queixas da situação encontrada em Portugal a D. João, o rei ficou com o segundo, dando ao inglês poderes quase de chefe do governo do Reino de 
Portugal, que assumia uma forma caracteristicamente militar. A chegada desta notícia na metrópole foi o estopim da revolução que eclodiu no Porto, fazendo com que Beresford sequer pudesse desembarcar do navio.

Mesmo com as dissensões entre civis e militares no seio do "Sinédrio", sendo os homens de farda menos afeiçoados à causa revolucionária liberal, o pronunciamento militar ocorrido no Porto no dia 24 de agosto de 1820, convocou as Cortes para a feitura da Constituição. Em 15 de setembro eram destituídos os governadores em Lisboa. Somente no dia 11 de novembro chegava aos ouvidos de D. João, então no Rio de Janeiro, o relato dos acontecimentos.

Deflagrado o movimento constitucionalista em Portugal, especialmente a partir da instalação das Cortes em 26 de janeiro de 1821, havia grande expectativa quanto à atitude que seria tomada por D. João VI, a esta altura, no Rio de Janeiro desde 1808. Existia a possibilidade de que ele jurasse a Constituição, como de fato o fez, mas também que, inspirado nas antigas instituições e hábitos monárquicos, pudesse optar pela permanência no Brasil e a convocação de Cortes próprias, provocando o isolamento do movimento constitucionalista e, com a perda momentânea da colônia, derrotá-lo. "Tal idéia, da existência em solo brasileiro de Cortes, estava tão associada à corrente mais antiliberal e absolutista que cercava o rel ${ }^{47}$.

O juramento sob a Constituição e o retorno do Rei para Portugal foi uma vitória momentânea do liberalismo. Aliás, o termo "liberalismo", enquanto definidor de uma nova ordem política no processo histórico de desenvolvimento do capitalismo, foi utilizado primeiramente na Espanha, em 1812, designando os que tinham sempre o vocábulo liberdade em seus lábios e que recorriam ao termo pejorativo de servis para nomear seus adversários ${ }^{48}$. No momento seguinte, e espalhando-se pelo mundo, a palavra liberalismo passou a significar aquele que é amigo da "ordem" e da lei importante frisar este ponto - que reconhece o direito alheio, com uma clara significação referida ao constitucionalismo e seu paradigma legalista. Em 1822, o termo aparece justamente nos dois Manifestos proclamados pelo Príncipe Regente publicados em 1ํ e 6 de agosto, redigidos por Joaquim Gonçalves Ledo e José

\footnotetext{
${ }^{47}$ BERNARDES, Denis Antônio de Mendonça. (2006). O Patriotismo Constituicional: Pernambuco, 18201822, São Paulo-Recife: Editora Universitária, p. 326.

${ }^{48}$ Peixoto, Antônio Carlos et al., O Liberalismo no Brasil Imperial, op.cit, p. 85.
} 
Bonifácio, respectivamente. O primeiro, empregou o vocábulo contra o "odioso sistema colonial" no Brasil. Já o segundo manifesto, na mais perfeita tradição coimbrã, visava demonstrar que a consolidação da liberdade no Brasil salvaria Portugal de uma nova classe de tiranos que se encontravam nas Cortes:

"Deixai que clamem que nos rebelamos contra o Rei: Ele sabe que o amamos, como a um Rei cidadão, e queremos salva-lo do afrontoso estado de cativeiro, a que o reduziram; arrancando a máscara da hipocrisia a demagogos infames e marcando com verdadeiro liberalismo os justos limites dos poderes políticos, 49 .

A batalha em torno do liberalismo lusitano, impregnado do sentimento de liberdade política e dos direitos do povo defendidos pelos juristas, ganhou movimento na imprensa em geral, único foro até então existente para esse debate. $E$ as disputas que se travavam em torno das idéias de "ordem" e do seu correlato legalismo, da limitação dos poderes do Absolutismo Português, foram canalizadas para um instrumento formal que realizava, na prática, todo este ideário político: a Constituição ${ }^{50}$. A oração de ação de graças proferida por um cônego da Real Capela do Rio de Janeiro, no primeiro aniversário da "regeneração política", assim expressava o sentimento sobre a Constituição:

"Constituição é a defesa do Estado, o apoio do trono, a escala da grandeza, a melhor herança do povo, o nível da perfeita igualdade cívica. Constituição é o código universal da sociedade, a regra infalível da justiça, o Evangelho político da Nação, o compêndio de todas as obrigações, o manual político do cidadão., 51

Percebemos com clareza neste pequeno excerto a formação dos principais valores da cultura política do liberalismo luso-brasileiro do Oitocentos, o qual considerava a igualdade perante a lei como condição primeira do cidadão, ao que se denominava a fruição e o gozo das liberdades civis e públicas, chocando-se contra a tirania do trono português que deveria ser freado legalmente. A Constituição encarnava justamente esta limitação legal à qual o soberano também estaria necessariamente obrigado, daí as disputas ideológicas travadas pelos juristas a propósito do seu conteúdo, do seu alcance, e das suas finalidades. De acordo com a máxima liberal

\footnotetext{
${ }^{49}$ Idem, p. 88.

50 Idem, p. 89.
} 
segundo a qual tudo o que não era proibido pela lei seria permitido, o confronto de idéias girava em torno do que seria ou não proibido no plano da legalidade, do que derivava logicamente ser este um domínio exclusivo dos juristas, fazendo com que as controvérsias a esse respeito veiculadas na imprensa estivessem em vias de especialização, isto é, na iminência de saltar para fora do âmbito político, e pretensamente se estabelecer enquanto discurso científico: neutro e objetivo.

\section{5 - Uma Nova "Ordem" para o Brasil.}

Vejamos de forma bastante sintética como os diversos "liberalismos" estiveram presentes na cultura periódica política brasileira e influenciaram o surgimento do periodismo especializado em direito no Brasil a partir de dois estudos realizados, abordando, cada um deles, dois momentos distintos da primeira metade do século XIX: o trabalho de Isabel Lustosa no período da independência, e o de Arnaldo Contier no período entre 1822 e 1842, às vésperas do surgimento do jornalismo no Brasil em 1843. Assim o fazendo, estaremos mais atentos à história do conceito de "ordem" segundo o paradigma legalista de matriz constitucional em debate no império lusobrasileiro, e a sua apropriação pelo discurso conservador, o que não quer dizer que este ideário tenha sido exclusivo do partido conservador, segundo a historiografia que utiliza os partidos imperiais como parâmetro de referência. Lembramos, a esse respeito, o discurso de José de Alencar proferido na sessão da Câmara dos Deputados do dia 17 de agosto de 1870, no qual ele nos dá toda a demonstração do quanto o liberalismo, conservador ou progressista, não tinha dono: "Senhores, o Partido Liberal não tem direito e propriedade a respeito das medidas tendentes a garantir a liberdade individua ${ }^{52 "}$.

Isabel Lustosa atribui à geração de 1790, formada entre outros por José Bonifácio de Andrada, José da Silva Lisboa, Luis Augusto May e Hipólito da Costa - todos eles formados na Universidade de Coimbra - a paternidade da utilização da imprensa periódica comum no início do século XIX como veículo de propaganda ou

\footnotetext{
${ }^{51}$ Idem, p. 91.

${ }^{52}$ ALENCAR, José de. (1977). Discursos Parlamentares de José de Alencar _ Deputado-Geral pela província do Ceará (1861-1877), Brasília: Câmara dos Deputados, p. 544.
} 
"amortecimento" das idéias liberais no Brasil. Defendiam eles um liberalismo, a bem dizer, adaptado às necessidades da elite agrária e escravocrata brasileira, que receava uma revolta como a que ocorreu no Haiti em 1792, já ensaiada na Revolta dos Alfaiates na Bahia em 1798, esta sim, a primeira revolta brasileira genuinamente popular, prometendo que "todos os cativos pardos e pretos ficariam libertos sem que houvesse mais escravo algum ${ }^{53 "}$. O liberalismo de cunho radical, é preciso que se frise logo de início, fora deixado de lado pelos intelectuais reformadores brasileiros no início do século XIX.

A partir daí, toda e qualquer idéia de revolução seria na maioria das vezes associada à "(des)ordem" e repelida, tida justamente como contrária às leis. É que para o liberalismo moderado a idéia de uma Constituição, a par de dar uma sistematicidade interpretativa ao conjunto tumultuário de leis seria o ponto de encontro onde desaguavam tanto os interesses de uma nova burguesia em busca de espaço político, quanto os da monarquia. Era como se apenas com a Constituição a noção de "ordem" estaria preservada, de um jeito ou do outro. Para efeito da análise dos conceitos e o papel do constitucionalismo naquele momento preciso, as Cortes em Portugal acusavam os jornalistas brasileiros como "inimigos da verdade", imputando-lhes as alcunhas de "sedição, delírio, atentado contra a Pátria, contra a Nação, contra a felicidade pública, etc ${ }^{54 "}$.

Longe de supor alguma univocidade quanto às idéias defendidas, o imenso repertório dos juristas-jornalistas no período que antecedeu à Independência emanava dos mais variados matizes. No dia 15 de setembro de 1821, surgia o periódico "Reverbero Constitucional Fluminense", de Joaquim Gonçalves Ledo e Januário Cunha Barbosa, ambos maçons, conhecidos nas lojas como os irmãos "Diderot" e "Kant", pregando a emancipação política da colônia repetindo os mais batidos chavões de $1789^{55}$. "O Espelho", que veio à lume no dia $1^{\circ}$ de outubro de 1821, sob o comando de Ferreira de Araújo, era um jornal monarquista que atacava os portugueses mas defendia o rei" ${ }^{36}$.

\footnotetext{
${ }^{53}$ LUSTOSA, Isabel. (2000). Insultos Impressos: a guerra dos jornalistas na Independência (1821-1823), São Paulo: Companhia das Letras, p. 49.

${ }^{54}$ Idem, p. 136-137.

${ }^{55}$ Idem, p. 172.

${ }^{56}$ Idem, p. 149.
} 
Estes dois periódicos, segundo Isabel Lustosa, protagonizaram a primeira polêmica da imprensa brasileira da disputa pelo "minguado" público leitor da capital, dando uma noção da "diferença de postura com relação aos portugueses que marcará a atuação dos liberais e dos monarquistas. Ledo e seu grupo, do qual faziam parte vários portugueses, tenderão para uma atitude menos radica ${ }^{57}$."

O "Malagueta", de Luis Augusto May, veio a lume em dezembro de 1821, anunciando que escrevia em nome dos brasileiros com "conhecimento da matéria constituciona ${ }^{58 "}$. Para demonstrar o quanto o constitucionalismo era sinônimo de ordem e de retidão, lançava farpas contra o jornal o "Espelho", aludindo que ele sim escrevia de forma "constitucional e vantajosa para todos ${ }^{59 "}$, utilizando-se até mesmo da expressão "ultrabrasileiro60", em oposição ao "ultramontanismo", termo ao qual estamos mais acostumados a ver nas fontes historiográficas.

Já no estudo que realizou sobre a imprensa e a ideologia em São Paulo entre os anos de 1822 e 1842, período no qual se assistiu a uma série de revoltas liberais intensamente noticiadas pela imprensa periódica, às vésperas do surgimento do periodismo jurídico no Brasil, Arnaldo D. Contier destacou que:

\begin{abstract}
"A análise dos periódicos, em especial dos fins do Primeiro Reinado e inícios do Período Regencial, tem por objetivo fundamental estudar o vocabulário político e social dos agentes sociais paulistas a fim de diagnosticar os matizes da ideologia dominante, procurando compreender os comportamentos da elite intelectual e política em relação à tomada de consciência do conceito de independência política, no momento em que os quadros burocráticos e políticos, outrora ocupados pelos portugueses ou colonialistas, passaram a ser disputados pelos representantes da elite senhorial paulista, em particular, e brasileira, em geral. ${ }^{, 61}$
\end{abstract}

Encontramos neste importante trabalho de pesquisa, a preocupação de fazer uma história dos conceitos em voga no período por ele delimitado, visando compreender a inspiração política dominante dos protagonistas das revoluções brasileiras da primeira metade do Oitocentos, e a função estratégica dos periódicos

\footnotetext{
${ }^{57}$ Idem, p. 149.

58 Idem, p. 173.

59 Idem, p. 169.

60 Idem.

${ }^{61}$ Contier, Arnaldo Daraya. (1979). Imprensa e Ideologia em São Paulo, 1822-1842: matizes do vocabulário político e social, Petrópolis: Vozes, p. 13
} 
como propagadores de "idéias políticas, filosóficas e sociais" ${ }^{62 " . ~ D e s t e ~ p e r i ́ o d o, ~}$ destacam-se as revistas "O Farol Paulistano" (1827-1831), "O Novo Farol Paulistano" (1831-1835), "O Justiceiro" (1834-1835), "O Caramuru" (1832-1833), "O Observador Constitucional" (1829-1832), sem contar com aqueles publicados em São Paulo e no Rio de Janeiro, como "O Tamoio" (1823), "A Aurora Fluminense" (1827-1839), "O Carijó" (1832-1833), "O Federalista" (1832), a "Revista da Sociedade Philomática" (1833), "O Observador Paulistano" (1838-1842), “O Publicola" (1840), "O Nacional” (1836-1837), e a "Phoenix" (1838-1841).

Como redatores destes periódicos, se encontravam grandes nomes ligados à Regência, como José da Costa Carvalho, autor intelectual do motim de 23 de maio de 1822, e Antônio Diogo Feijó, principal redator de "O Justiceiro" e de "O Observador Paulistano". São relacionados ainda Libero Badaró (líder da revolução de 1830), Rafael Tobias de Aguiar (chefe do movimento de 1842), Francisco Inácio de Souza Queiroz (chefe militar do motim de 23 de maio de 1822), e tantos outros. E como característica comum entre eles, Contier apresenta a sua conclusão:

"Cada periódico paulistano e fluminense era redigido por um ou mais escritores
que, geralmente, eram agentes direta ou indiretamente ligados às famílias
possuidoras de terras, escravos, imóveis, ou eram, paralelamente, chefes
políticos locais interessados e divulgar suas idéias ou opiniões favoráveis ou
contrárias à situação política, social e econômica da Província de São Paulo ou
do Brasil. Esses locutores eram, portanto, políticos que ocuparam, durante
várias décadas, vários cargos públicos: vereadores, deputados ou senadores
(Assembléia Geral), deputados provinciais, após 1834, presidentes de
Províncias, juizes de paz, membros dos Gabinetes Ministeriais, entre outros"63.

Tomando como base estes dois estudos sobre as relações entre imprensa seriada e poder na primeira metade do século XIX, sobretudo na tentativa de desenhar a descontinuidade semântica do conceito de "ordem" e a função política por ele desempenhada, temos que para Isabel Lustosa, após a volta de D. João VI para Portugal, "a luta dos que aqui ficaram se travaria exclusivamente em torno do herdeiro da Coroa $^{64 "}$ e do estatuto constitucional da nova monarquia. É digna de nota a divisão entre "ultrabrasileirismo" e "ultramontanismo", indicando-nos a reivindicação naquele

\footnotetext{
62 Idem.

63 Idem, p. 14.

${ }^{64}$ Lustosa, Isabel, Insultos Impressos..., op. cit., p. 62.
} 
instante de uma identidade nacional distinta da metrópole. O "ultramontanismo" ficaria dali em diante pejorativamente associado à "desordem", ao autoritarismo lusitano, criando uma certa beligerância contra os portugueses que sobreviveria à Independência e ainda permaneceria no vocabulário político brasileiro até o final do Império.

Mesmo tendo sido exitosa a tarefa de desgrudar a figura de Pedro I de Portugal, os mais radicais tentariam obviamente limitá-lo no poder, engessando-o, desaguando novamente o debate em torno do formato constitucional da monarquia brasileira nascente. Coube a José Bonifácio a defesa das prerrogativas do monarca nas contendas contra esses liberais que pretendiam limitar-Ihe o poder em favor do legislativo. "Essas batalhas seriam travadas principalmente nas páginas da nascente imprensa brasileira ${ }^{65 "}$.

Já a análise dos léxicos levada a cabo por Arnaldo Contier às vésperas do periodismo jurídico, revelou como regra nos jornais a antinomia entre os conceitos de "absolutismo"/"liberalismo" até 1842, tanto em São Paulo como no Rio de Janeiro, num antagonismo frequentemente utilizado para refutar, negar e contestar o centralismo político da monarquia como um nefasto prolongamento do Antigo Regime português.

Em suma, o que deve ficar registrado neste momento é que a noção de "ordem" é reivindicada pelo conservadorismo em oposição aos liberais revoltosos e "desordeiros" nos periódicos políticos comuns, os únicos até então existentes, quando surge o jornalismo especializado em direito no Brasil, isto é, quando a literatura periódica jurídica se imagina pular para fora do âmbito político reivindicando um domínio exclusivo para si, sob a justificativa de uma pretensa neutralidade científica. Uma neutralidade que, internamente ao próprio discurso jurídico, garantiria a sua unidade e serviria de importante via de sistematização ensaiada modernamente desde a Lei da Boa Razão (1769). Na tentativa de dar sentido hermenêutico à balbúrdia de leis aplicáveis no Brasil naquela temporalidade, o discurso jurídico se emancipava das refregas ideológicas funcionando como único vetor da "ordem" e pretexto para a inauguração de uma nova estratégia na condução do governo imperial, que deveria ser entregue paulatinamente aos especialistas no trato das coisas públicas: os cientistas

${ }^{65}$ Idem. 
do direito que enfim teriam a seu dispor a melhor tecnologia de informação disponível para ao cumprimento do seu ofício.

O surgimento do periodismo jurídico, portanto, está inserido no debate historiográfico em torno do repertório interpretativo das leis ao alcance dos bacharéis e rábulas brasileiros do século XIX, sobretudo no encaminhamento das importantíssimas questões que gravitavam em torno da construção da cidadania e da formação de uma identidade nacional. $\mathrm{O}$ advento do jornalismo jurídico contribuiu enormemente, por exemplo, para dar aos juristas o mais amplo manancial interpretativo necessário para a atuação nas chamadas "ações de liberdade" estudadas por Sidney Chalhoub, Hebe Mattos e Keila Grimberg ${ }^{66}$. Havia argumentos e julgados para todo gosto nas sessões de doutrina ou de jurisprudência, favoráveis ou não aos escravos. Com efeito, na perfeita síntese desta última historiadora, "estamos em 1843, pouco depois das malsucedidas revoltas de $1842^{677,}$, o que não nos deixa esquecer de que o periodismo jurídico nasceu logo em seguida à reforma da organização judiciária empreendida pela lei de 3 de dezembro 1841, arquitetada justamente para aplacar o ímpeto revolucionário do início o século XIX, mediante a supressão de importantes garantias civis, como a limitação do direito ao habeas corpus, o uso indiscriminado das prisões preventivas, a restrição do pagamento da fiança, etc.

Fizemos a relação entre a imprensa periódica política e os diversos "liberalismos" em disputa no Brasil na primeira metade do Oitocentos, para chegarmos justamente ao ponto em que, no bojo das querelas jurídicas disputadas nas páginas jornalísticas comuns, trazendo em si o espírito do reformismo conservador que animava as transformações das instituições imperiais, surgiu o periodismo jurídico em nosso país, com a publicação da "Gazeta dos Tribunaes", no Rio de Janeiro, em 10 de janeiro de 1843, mesmo ano em que foi criado o Instituto dos Advogados Brasileiros (IAB). E a coincidência de datas não é fortuita. O mesmo Conselheiro Francisco Alberto Teixeira de Aragão, que havia incentivado como nenhum outro a instalação do IAB, foi também o fundador da "Gazeta dos Tribunaes". Se o direito merecia uma linguagem cientificista própria, diferente do discurso apaixonado das tribunas parlamentares, a sua

\footnotetext{
${ }^{66}$ Ler a esse respeito: Grinberg, Keila. (2002). O Fiador dos Brasileiros. Rio de Janeiro: Civilização Brasileira, pp. 234-235.

${ }^{67}$ Ibidem, p. 167.
} 
casa também deveria ser distinta. É neste contexto de separação entre a linguagem política e a linguagem jurídica, que podemos compreender a concepção do direito defendida por Augusto Teixeira de Freitas, um dos fundadores do IAB no mesmo ano de 1843:

\begin{abstract}
"Em questões abstratas de jurisprudência, não posso compreender que se desenvolvam paixões; não sei também que fruto se possa colher dos assaltos de uma primeira idéia, e arrebatamentos de entusiasmo, em matéria de pura observação e raciocínio",68.
\end{abstract}

Podemos observar, com efeito, que o "romanismo" do autor da Consolidação, ou o seu legalismo extremado, representava uma filiação a uma determinada visão do direito como sendo pretensamente isento de idéias políticas e filosóficas, de paixões e impulsos que não a suposta ratio legis. $\mathrm{E}$, alçando o constitucionalismo como dogma intransponível, o "Jurisconsulto do Império" radicalizou o argumento da neutralidade positivista da lei e sustentou, num artigo de doutrina encartado no periódico jurídico "O Direito", em 1876, a inconstitucionalidade da Lei do Ventre Livre: "Não açulamos reclamantes, não suscitamos embaraços. Só pugnamos pelo fiel cumprimento das leis: 'Sejamos escravos das leis (fala Cícero), para que possamos ser livres'69,"

Com efeito, o prefácio deste primeiro periódico jurídico brasileiro, a "Gazeta dos Tribunaes”, embora fizesse alusão a quatro malogradas tentativas anteriores ${ }^{70}$, trazia, logo em seu primeiro parágrafo, a circulação das idéias mais avançadas ao mencionar que "Há muito tempo meditávamos sobre a utilidade pública, que devia resultar da organização de uma gazeta dos tribunais, a exemplo das de diferentes nações estrangeiras ${ }^{71}$.

Era a primeira vez que o campo jurídico no Brasil formulava um projeto de amplificação de uma leitura liberal do direito específico para o seleto público de juristas,

\footnotetext{
${ }^{68}$ Meira, Sílvio. (1983). Teixeira de Freitas. O Jurisconsulto do Império, Vida e Obra. $2^{\underline{a}}$ ed. Brasília: Cegraf, p. 142.

${ }^{69}$ O DIREITO. (1876). vol. 9, p.609.

${ }^{70}$ O Jornal do Tribunal Supremo de Justiça, Trombeta d'Astrea, Gazeta de Tribunnaes e Espelho da Justiça, que foram cogitadas por alguns juristas, mas não tiveram mais de um número ou sequer saíram do prelo. Cândido Mendes de Almeida relaciona em seu Código Philipino, p. LXII, um total de 7 revistas jurídicas nacionais que utilizou em suas consultas, dando os dados da fundação e extinção de cada uma delas.
} 
aparecendo como porta-voz de uma nova mentalidade, refletindo um novo exercício de poder através da vocalização dos diversos sentidos da lei enquanto vetor de normalização. Entendemos por "norma", segundo Canguilhem, "certos estados ou comportamentos que, em relação à polaridade dinâmica da vida, são apreendidos sob forma de valores negativos ${ }^{72}$. O redator se vangloriava com todas as letras do "progresso das luzes", anunciando que a difusão das questões forenses seria benéfica para a "administração da justiça, da qual depende essencialmente a felicidade dos povos". Os juristas seriam os condutores da salvação do restante da população, os corifeus da vontade pública, os únicos capazes de trazer a felicidade e a civilização. Saindo-se vitorioso o paradigma legalista, apenas a lei seria a garantia da "ordem" e do bem comum, motivo pelo qual seria preciso "afinar o discurso", como se diz vulgarmente, através da divulgação periódica de artigos de doutrina e de julgados que dessem aos juristas de todo o Império o caminho para a sua correta interpretação.

A garantia da "ordem" (rectius: "felicidade") também não poderia jamais prescindir da transparência e publicidade dos atos de governo, das decisões judiciais e das discussões parlamentares. Tanto a transparência quanto a publicidade deveriam ter lugar nas páginas especializadas de um periódico jurídico, numa interlocução exclusivista entre os únicos que poderiam fazer algum juízo sobre as "coisas" da lei, detentores de um saber privilegiado, num domínio que somente a eles pertencia. $O$ restante do povo aparece simplesmente como uma massa "desinteressada" a ser retoricamente conduzida pelos homens de anel de grau. Eis as intenções dos redatores da "Gazeta" a esse propósito:

\footnotetext{
"A publicidade dos julgamentos e da marcha dos processos é a alma da justiça, é a melhor garantia social, que mais contribui para que o povo se habitue a tomar interesse nos resultados das discussões e trabalhos judiciários; e para que, ainda os menos instruídos, conheçam por si a maneira porque se lhes administra sua vida, honra e fazenda. De que serve o patriotismo com que $o$ público mostra anualmente interessar-se na discussão das boas leis perante $o$ poder legislativo, e de que servirão mesmo essas boas leis, se o seu efeito fica limitado à pura teoria! ${ }^{73}$
}

\footnotetext{
${ }^{71}$ GAZETA DOS TRIBUNAES. (1843). vol. 1, p. 1.

${ }^{72}$ Canguilhem, Georges. (1990). O Normal e o Patológico, Rio de Janeiro: Forense Universitária, p. 96.

${ }^{73}$ GAZETA DOS TRIBUNAES. (1843). vol. 1, p. 1.
} 
E na tentativa sempre de estabelecer um corte entre o periodismo jurídico com o meio político do qual se especializou, o mesmo prólogo da "Gazeta dos Tribunaes" deixa claro que "nunca aprovamos essas reclamações vagas e virulentas que por muitas vezes tem saído pelos prelos contra a administração da justiça ${ }^{74 ",}$, permitindonos, em primeiro lugar, ver como o jornalismo político não era estranho aos redatores da revista. E, depois, identificar como a discussão política dos assuntos de maior interesse para o país, tecida tradicionalmente nos meios jornalísticos comuns, passaria a ser doravante deslegitimada para então ser retomada "cientificamente", no âmbito que se the entende particular, ou seja, no discurso do campo jurídico e longe das paixões políticas. Dali em diante os assuntos de governo seriam tratados e fetichizados tecnicamente pelos juristas, que lhes davam a pretensa roupagem da neutralidade com que deveriam ser tratadas. O especialismo jurídico se apropriava, dessa maneira, das discussões e decisões políticas mais relevantes, reivindicando um estatuto de "verdade", retirando-as das ruas onde já haviam causado bastante barulho nas primeiras décadas daquele século.

Ainda perseguindo as interseções entre o periodismo comum e o especializado, verificamos que no segundo número da "Gazeta" são anunciados dois correspondentes com longa produção no jornalismo político comum. O primeiro é Diogo Soares da Silva de Bivar, que foi redator do periódico "Idade d'Ouro do Brasil" e fundador do primeiro jornal literário do Brasil, intitulado "As Variedades", dado a prelo em 1812, na Bahia. E, por último, João Manuel Pereira da Silva, que foi redator do "Jornal do Comércio", do "Jornal de Debates" e da "Revista Popular".

Esta primeira revista jurídica publicava a parte geral do "Jornal do Commercio" no que respeitava à legislação; os acórdãos e sentenças dos tribunais e juízes; as discussões mais importantes do foro; dúvidas e omissões encontradas pelas "autoridades"; crônicas; nomeações, residências, posses, óbitos, aposentadorias; uma sessão policial; outra de tribunais estrangeiros; e de publicações literárias. Cinco anos mais tarde, precisamente em 8 de julho de 1848, foi publicada a "Nova Gazeta dos Tribunaes", de propriedade de Antônio Manoel Cordeiro, circulando até 21 de março de 1850.

\footnotetext{
${ }^{74}$ Idem.
} 
O mesmo Antônio Manoel Cordeiro levou adiante o periodismo especializado novamente em 1856, quando passou a editar a "Revista dos Tribunaes", cujo primeiro número saiu numa terça-feira, dia 13 de janeiro de 1856. Nela fazia logo no primeiro número uma alusão explícita à tecnologia de imprensa na sua "vantagem em se dar a quaisquer conhecimentos humanos, em geral, a maior publicidade, de modo a, tornando-se mais populares, influírem mais direta e poderosamente no desenvolvimento da humanidade ${ }^{75 "}$. A finalidade precípua da aliança do direito e imprensa periódica não poderia ser outra senão arregimentar aliados e influir "poderosamente" - a palavra por ele empregada é bastante significativa - nos destinos da civilização.

A nova tecnologia de informação tinha esse caráter subjetivante que se exercia no ingresso do Brasil na modernidade, através das transformações liberalizantes em meados do Oitocentos. O Brasil naquele século passava por profundas transformações, alterando a sua ordem política e jurídica nacionais. O Código Comercial de 1850 uniformizou as leis relativas às fábricas, aos contratos mercantis, as hipotecas etc., deixando menos arriscadas as transações comerciais. No mesmo ano, foi promulgada também a Lei de Terras e a Lei Eusébio de Queirós, que não podem ser analisadas isoladamente. Com efeito, estas importantes reformas legislativas permitiram, no Brasil, respectivamente, o fluxo de capitais, de terras e de mão-de-obra. Como consequência, no ano seguinte se formaram 11 companhias na Corte, enquanto que de 1838 a 1850 foram apenas 4; entre 1852 e 1859 surgiram mais 135 companhias. Das 69 empresas estrangeiras e brasileiras registradas em 1866, excluindo-se os bancos, apenas 3 eram fabris. Havia 27 empresas de transporte (fluvial, marítimo, ferroviário e rodoviário), 22 companhias de seguro, 4 de mineração e 13 de serviços públicos urbanos ${ }^{76}$.

Também de grande valia para a compreensão do alcance do conjunto das reformas legislativas empreendidas entre as décadas de 1840/50, é o destaque que Keila Grimberg dá às discussões em torno da codificação das leis civis do Império ainda no ano de 1854, quando após a promulgação do Código Comercial, o então

\footnotetext{
${ }^{75}$ REVISTA DOS TRIBUNAES: dos juizes e factos judiciais, do foro e da jurisprudencia. (1856-1859), Rio de Janeiro: Typ. Universal de Laemmert, p. 1.
} 
ministro da Justiça José Thomaz Nabuco de Araújo iniciou junto à Augusto Teixeira de Freitas as tratativas para a elaboração de um plano geral de redação do Código Civil ${ }^{77}$. É digno de nota que o próprio Teixeira de Freitas, na introdução da terceira edição da sua "Consolidação das Leis Civis", afirma expressamente ter se servido do periodismo jurídico ao longo da empreitada de que fora incumbido, ao dizer que bebeu "gradualmente nas três fontes da jurídica opulência - Legislação, Doutrina, Jurisprudência - ; a exemplo dos Juristas Franceses, tão felizmente imitado nas duas revistas dos Srs. José da Silva Costa e J. J. do Monte"78, numa referência aos editores, respectivamente, dos periódicos "Revista Jurídica" (1862) e "O Direito" (1873).

Aliás, o mesmo Teixeira de Freitas escreveu diversos artigos em revistas jurídicas após a suposta "monomania religiosa" a que ficara acometido depois da rescisão do contrato com o governo imperial ${ }^{79}$. Os periódicos permitiram-lhe retornar aos debates jurídicos nacionais, ocupando novamente o lugar de destaque abalado com o malogro da codificação civil imperial e com a fama de alienado mental, amplificando a sua rede de influências, divulgando o legalismo irrestrito e atacando acidamente os seus adversários. Para este desiderato, o periódico jurídico era um instrumento bastante eficiente. Com esta finalidade, Teixeira de Freitas escreveu uma carta ao proprietário da revista "O Direito", datada de 20 de dezembro de 1875, aludindo a um "verbal convite" para que então colaborasse com a revista:

\begin{abstract}
"Meu estimadíssimo colega. Honrado por V. S. com o verbal convite para colaborar em sua interessante revista - O Direito -, acedi prontamente; resolvendo logo encetar por uma defesa do relatório de 4 de dezembro de 1858, assinado por três notáveis jurisconsultos, dos quais vive ainda o Sr. conselheiro José Tomás Nabuco de Araújo,80.
\end{abstract}

Logo nas primeiras linhas escritas no periódico, uma simples carta de aquiescência com o convite formulado pelo proprietário da revista, Freitas não perde tempo e retoma com toda a energia seu objeto de argumentação exatamente no ponto

\footnotetext{
${ }^{76}$ Benchimol, Jaime Larry. (1992). Pereira Passos: um Haussmann Tropical, Rio de Janeiro: Biblioteca Carioca, p. 44.

${ }_{78}^{77}$ Grinberg, Keila. (2002). Código Civil e Cidadania. Rio de Janeiro: Jorge Zahar Editor, p. 12.

${ }^{78}$ Freitas, Augusto Teixeira de. Consolidação das Leis Civis, Introdução, p. VI.

${ }^{79}$ Ver o debate em torno da doença mental de Teixeira de Freitas em: Neder, Gizlene e Cerqueira Filho, Gisálio. (2001). Idéias Jurídicas e Autoridade na Família, Rio de Janeiro: Ed. Revan; e Pena, Eduardo Spiller. Pajens da Casa Imperial, op. cit.
} 
em que parou antes do seu desafortunado silêncio. Por isso menciona o relatório da comissão de 4 de dezembro de 1858, que aprovou o trabalho por ele empreendido até aquela época. Voltava à esgrima para se defender das seguidas críticas ao método por ele concebido na consecução do "esboço" de Código Civil, e atacar os seus contentores que abusavam das paixões políticas a interferiam danosamente nas coisas do direito:

\begin{abstract}
"Homens de tempera metálica não têm saber nem virtudes, não julgarão o mérito de seus filhos por qualidades opostas.

Durma esse inimigo que ainda não despertou, e provavelmente não virá inquietar-nos. Aguardemos o projeto do Código Civil, e quanto por ora cumpre à V.S. fazer seja largueza do seu primitivo programa e à mim desde já servi-lo como algumas investigações de jure constituto.

Se prestei-me logo ingenuamente, a contribuir para os escritos da Revista, foi na esperança de poder discutir o projetado Código Civil, foi também na de poder pronunciar meu voto sobre qualquer publicação jurídica,,81.
\end{abstract}

Imediatamente, refere-se a um "livro publicado nesta corte, composição de outro notável jurisconsulto, sob o título - Direitos de Família", que o havia acusado "de não preencher os intuitos da ciência o meu princípio classificador"82. Tratava-se da primeira obra jurídica de Lafayette Rodrigues Pereira, que tinha trabalhado em seu escritório ainda na mocidade. Lafayette era um político liberal que havia, em 1870, assinado o Manifesto Republicano, defendendo plataformas políticas arrojadas para a ordem jurídica conservadora então vigente, centrada no direito constitucional de propriedade acima de qualquer outro, tal como defendido por Freitas.

No mesmo escrito, prossegue o "Jurisconsulto do Império" reafirmando sua "fé nas direções científicas", aguardando a oportunidade para defender o seu método quando viesse à tona o projeto de codificação civil que estava naquele instante sob a batuta de Nabuco de Araújo, que permanecia prestigiado junto ao governo imperial. Entretanto, tudo leva a crer que Freitas acusava o seu antigo "consorte" de ter aceitado a empreitada que somente a ele pertencia, não em razão de eventuais divergências "científicas" quanto ao método ou às matérias elaboradas, mas por uma questão de "escrúpulo". Para ele a atitude de Nabuco soava como uma enorme traição:

\footnotetext{
${ }^{80}$ O DIREITO. (1876). vol. 9, p. 5.

${ }^{81}$ Idem, p. 8.

82 Idem, p. 6.
} 
"Se não me é dado por consciência na ciência, aparentemente com o governo imperial por divergências do plano, apresentar eu mesmo um projeto de Código Civil ao gosto do tempo; não está no mesmo caso quem, professando outras idéias, não tiver motivos de escrúpulo. Na passagem, enquanto o regime das coisas não fornecer outros dados, reputo de meu dever trabalhar quanto possa para o melhor possível na quadra, ${ }^{, 33}$.

Disparou em seguida uma dura crítica a outro artigo de doutrina de autoria do co-redator da mesma revista, o Conselheiro Ribas, sobre a locação de serviços civil ${ }^{84}$, que havia ocupado as primeiras páginas do primeiro volume do periódico. Mas a divergência aparentemente técnica entre os dois afamados jurisconsultos do Império, não conseguia acobertar o fato de que Ribas foi o Secretário da comissão que julgou o seu trabalho à frente da codificação civil, juntamente com outro conhecido desafeto seu, ninguém menos do que Caetano Alberto Soares ${ }^{85}$. Durante os trabalhos da comissão, Ribas teceu críticas ao modelo adotado por Freitas e apresentou um substitutivo aos artigos $1^{\circ}$ ao $7^{086}$. Em 1879, na introdução do livro "Primeiras Linhas sobre o Processo Civil", Teixeira de Freitas revidaria a crítica mais uma vez ao comentar um livro de Ribas saído do prelo, referindo-se à "excrescência" ${ }^{87}$ da teoria nele exposta.

Em resumo, essa comunicação tão ampla, tão vasta e tão atual com o público especializado de leitores, é um exemplo de como a tecnologia de informação periódica do direito se tornaria um campo aberto de batalhas em torno das novidades doutrinárias e jurisprudenciais, nacionais e estrangeiras, encaminhando importantes questões relativas à construção da cidadania e da identidade nacional no século XIX. $\mathrm{Na}$ verdade, nada escaparia ao seu enquadramento jurídico. No pensamento de Jurandir Freire Costa:

"O século XIX assistiu à invasão progressiva do espaço da lei pela tecnologia da norma. O Estado moderno procurou implantar seus interesses servindo-se,

\footnotetext{
83 Idem, p. 8.

${ }^{84}$ Idem, p. 193.

${ }^{85}$ Meira, Silvio, Teixeira de Freitas..., op. cit., p. 217.

${ }^{86}$ Idem, p. 221.

${ }^{87}$ Freitas, Augusto Teixeira de. (1879). Primeiras Linhas sobre o Processo Civil. Tomo I. Rio de Janeiro: Typographia Perseverança, Introdução, p. XV.
} 
predominantemente, dos equipamentos de normalização, que são sempre inventados para solucionar urgências políticas,88.

Uma nova subjetividade era moldada por uma demanda cada vez maior de informação, que trazia em seu bojo um leque de novos hábitos, de novas intelectualidades, novas sensibilidades artísticas, novos corpos, novos lares e fábricas, novos sentimentos e desejos. Da aceleração cada vez maior do tempo nascia sempre a idéia de "estar na moda", de conduzir-se naquilo que é atual, no gosto pela novidade, colocando incessantemente em circulação as novas idéias sob a forma de modelos a serem seguidos. O periodismo jurídico é indissociável desse contexto em que funcionou como importante dispositivo de propagação e formação de sentidos na aplicação da lei, como uma máquina semiotizante dentro da rede de outras tantas máquinas que compunham um novo exercício de poder diferente daquele até então encenado. De qualquer modo, em meio a tantas transformações, o país fervilhava de projetos que se apresentavam para dar identidade à nação que começava a sentir os avanços da modernidade. Alguns alcançavam o status da preponderância no processo de homogeneização, quase sempre traduzidos pela linguagem jurídica: Leis de Terras, Abolição do Tráfico, Código Comercial, Código Civil etc. Lemos na "Revista dos Tribunaes" nitidamente este poder de amplificação e ressonância dos periódicos especializados em direito:

"Se pois é evidente o proveito que resulta à humanidade da propagação, por
meio de folhas periódicas de quaisquer doutrinas sãs, porquanto fica
expendido, sobre de pronto a conveniência (se não é necessidade),
especialmente para a gente do foro, da publicação de um jornal forense em um
país, onde nenhum existe ainda,"89.

E prossegue o redator a vangloriar não apenas os benefícios do dispositivo de imprensa, mas também quanto às próprias idéias ressonantes estampadas nas suas páginas, anunciando o primado na norma como tecnologia de poder, disciplinando a sociedade como um todo, a partir dos postulados liberais de liberdade e propriedade como garantidores da "ordem" vigente:

\footnotetext{
${ }^{88}$ Costa, Jurandir Freire. (1989). Ordem Médica e Norma Familiar. Rio de Janeiro: Edições Graal, p. 5051

${ }^{89}$ REVISTA DOS TRIBUNAIS, p. 1.
} 


\begin{abstract}
"Mas ninguém duvida que das ciências, cujas doutrinas estão mais estritamente ligadas ao fim do homem o tem mais geral interesse e aplicação, é uma a jurisprudência.

Por ela conhece o homem quais os seus direitos, e deveres, em geral, podendo tornar-se grande pela obediência a estes, como se exprime um filósofo contemporâneo; ela fazendo-o saber o que é a lei, a norma das ações, ensinao a distinguir o justo do injusto, e o habilita a viver em sociedade; por ela são garantidas a liberdade, propriedade, honra e vida dos cidadãos, enquanto todas estão debaixo da égide do direito e da justiça, que a jurisprudência tem por fim ${ }^{, 90}$.
\end{abstract}

Como quer que seja, o rol de periódicos brasileiros da segunda metade do Século XIX é bastante extenso e tiveram destacada influência em episódios históricos nacionais marcantes ${ }^{91}$ (vide as figuras de $n^{\circ} 1$ a 7). O elevado número de títulos demonstra indubitavelmente a importância que teve o jornalismo especializado em direito em nosso país, começando a despertar destacada atenção por parte dos pesquisadores deste ramo do conhecimento antes em Portugal do que no Brasil.

Se os homens do jornalismo político e os do jornalismo jurídico eram os mesmos, isso quer dizer que o periodismo jurídico há de ser cotejado na totalidade do movimento de imprensa oitocentista, do qual se bifurca ou se especializa pelo artifício de uma linguagem comunicacional específica, que tinha estratégias e locutores também específicos, no encaminhamento das várias tonalidades do liberalismo brasileiro na passagem para a modernidade.

\title{
6 - Conclusão
}

Ao final deste trabalho, importa destacar do periodismo jurídico oitocentista a forma com que Savigny o utilizou, isto é, como instrumento mais ou menos consciente de disputa entre as várias escolas de direito em contenda, o que parece ter sido uma característica constitutiva marcante do periodismo dali em diante, não apenas na Alemanha, mas também no Brasil, até onde nos propomos investigar numa etapa introdutória ao tema. Ressalvando cuidadosamente os contextos históricos distintos em

\footnotetext{
90 Idem.

91 Demonstramos em nossa Dissertação de Mestrado do Programa de Pós-Graduação em Sociologia e Direito/UFF, intitulada "A Revista O Direito - Periodismo Jurídico e Política no final do Império do Brasil",
} 
que o periodismo alemão e brasileiro se deram, podemos observar, então, que o aparecimento da imprensa jurídica seriada em nosso país, especificamente no ano de 1843, com a publicação da "Gazeta dos Tribunaes", deita as suas origens não só no desenvolvimento como um todo da imprensa no Brasil, mas como correlato também do próprio desenvolvimento do nosso capitalismo e das contradições que ele implicava no âmbito do discurso jurídico.

$\mathrm{Na}$ busca de um estatuto civilizatório que colocasse o país em pé de igualdade com as "nações mais cultas do mundo", como se dizia na época, o prefácio da "Gazeta dos Tribunaes" se alinhava com o pensamento que se propunha inovador no encaminhamento das questões jurídicas agora no foro próprio que the era destinado, pretensamente científico e neutro, isto é, livre das exacerbações políticas da imprensa comum. Ofuscada pelo que chamou de "progresso das luzes" ${ }^{92 ", ~ a ~ i m p r e n s a ~ p o l i ́ t i c a ~}$ passou a ser dali em diante desqualificada enquanto veículo dos debates jurídicos, as mais das vezes repletas de "reclamações vagas e virulentas ${ }^{93 ", ~ i n a u g u r a n d o ~ u m ~}$ especialismo que reivindicava as questões públicas como sendo um domínio exclusivo do seleto círculo de juristas, os únicos "iniciados" nas coisas da lei e do Estado. Não foi por acaso que naquele mesmo ano de 1843 era também fundado o IAB, já que além de ter um lugar próprio, as formas jurídicas deveriam também ter uma linguagem distinta, mantendo todo um invólucro solene e inacessível à maioria da população em torno do direito, basicamente a única forma de acesso às funções públicas imperiais.

Tampouco foi por acaso que naquela mesma década de 1840 havia sido reformada a organização judiciária enquanto uma reação conservadora aos movimentos liberais das primeiras décadas do século XIX. Neste contexto, ressaltamos a intrincada relação entre direito e política, sintetizada por Gisálio Cerqueira Filho do seguinte modo: "...o discurso jurídico (o que faz a lei e o que diz o direito) é em si mesmo uma prática ideológica... ${ }^{94 ”}$.

A estratégia de revestir o discurso jurídico de uma suposta neutralidade científica, capaz de dar-lhe maior autoridade e aceitação ao minar as resistências,

\footnotetext{
a relação entre Augusto Teixeira de Freitas e o proprietário do periódico O Direito, João José do Monte, sobretudo durante o desenrolar da questão religiosa (1873).

${ }_{92}$ GAZETA DOS TRIBUNAES, Vol. 1, p.1.

${ }^{93}$ Idem.

${ }^{94}$ Neder, Gizlene e Cerqueira Filho, Gisálio, Idéias Jurídicas e Autoridade na Família, op. cit., p. 94.
} 
expressa num templo e numa linguagem que o diferenciava das tribunas e dos jornais políticos, foi bastante efetiva do ponto de vista do exercício do poder numa sociedade que se disciplinarizava. Esta significativa mudança do eixo do discurso jurídico, agora definitivamente especializado, foi uma prática inserida numa nova tecnologia de subjetivação que encontrou, logo em seguida, em 1850, alcance nas leis que regulavam o trabalho, as terras e os capitais, abrindo as portas ao aburguesamento das mentes, dos corpos, das famílias e das cidades. Faltou apenas o código civil, mas que nem por isso ficou alheio ao fenômeno periodista do direito.

É claro que o divórcio definitivo entre direito e política jamais aconteceu. Lafayette Rodrigues Pereira escreveria, em 1869, que "A política atrai os grandes talentos. A glória modesta do civilista se ofusca diante dos fulgores da glória do orador parlamentar e do jornalista ${ }^{95 " . ~ N e s t e ~ b r e v e ~ e x c e r t o, ~ o ~ f u t u r o ~ m i n i s t r o ~ a p o n t a v a ~ o ~}$ jornalismo político como sendo ainda um grande chamariz para os egressos das faculdades de direito. Longe de supor uma superação completa entre a linguagem política e a jurídica, o que se viu foi que a elite intelectual brasileira, formada basicamente de juristas, oscilava entre o periodismo comum e o especializado, conforme a ocasião. Faziam direito com a política, e política com o direito. Mesmo no caso de Teixeira de Freitas, que se pensava isento das paixões políticas, ele emprestava decididamente seu ponto de vista para os defensores da escravidão no Brasil. Na sessão do dia 13 de setembro de 1887, numa demonstração clara de que política e direito são inseparáveis, o Barão de Cotegipe ainda bradaria no Senado um discurso contra a fuga em massa dos escravos das senzalas de Capinas, na província de São Paulo, sustentando o escravismo escudado na fórmula ensinada três décadas antes por Freitas na querela com Caetano Alberto no IAB, entendendo que a prole segue a mesma situação do ventre escravo, como o fruto segue a árvore:

"A minha opinião valia tanto quanto ou, valia nada ou muito pouco. (Não apoiados.) Chega o momento em que me encontro, sem o pensar, com este grande problema! Quando se tratou da lei de 1871, eu disse aos meus amigos: - Não nos devemos opor, embora, pelos princípios de direito romano e outros, o fruto siga a árvore". 96

\footnotetext{
${ }^{95}$ Pereira, Lafayette Rodrigues. (1869). Direitos de Família, Rio de Janeiro: B. L. Garnier_Livreiro-Editor, p. XXIV.

${ }_{96}$ Cotegipe, Barão de. (1887). Discursos Pronunciados no Senado pelo Sr. Barão de Cotegipe, Rio de Janeiro, Imprensa Nacional, p. 6.
} 
Como podemos ver, o estudo do periodismo jurídico do Oitocentos, encarado não apenas como fonte da pesquisa acadêmica, mas sobretudo quando colocado no lugar privilegiado de objeto, certamente pode nos trazer valorosas contribuições para a análise das idéias jurídicas brasileiras no século XIX.

\section{Bibliografia}

\section{Fontes Bibliográficas:}

Almeida, Candido Mendes de. (1870). Codigo Philippino ou Ordenações e Leis do Reino de Portugal, Rio de Janeiro: Typ. do Instituto Philomathico.

Cotegipe, Barão de. (1887). Discursos Pronunciados no Senado pelo Sr. Barão de Cotegipe, Rio de Janeiro, Imprensa Nacional.

Freitas, Augusto Teixeira de. (1876). Consolidação das Leis Civis do Império: Legislação do Brasil, Rio de Janeiro: B. L. Garnier. . (1879). Primeiras Linhas sobre o Processo Civil, Rio de Janeiro: Typographia Perseverança.

GAZETA JURÍDICA. Revista Semanal de Doutrina, Jurisprudência e Legislação. (1874). Rio de Janeiro: Typ. da Gazeta Jurídica.

GAZETA DOS TRIBUNAES: dos juízos e factos judiciaes, do foro e da jurisprudência. (1843-1846). Rio de Janeiro: Typ. Imparcial de F. de P. Brito, semanal.

O DIREITO. Revista de Legislação, Doutrina e Jurisprudência. (1873-1913). Rio de Janeiro: Typographia Teatral e Commercial, mensal.

Pereira, Lafayette Rodrigues. (1869). Direitos de Família, Rio de Janeiro: B. L. Garnier_Livreiro-Editor. 
Pitaval, Gayot de. (1746). Causes Celebres et Interessants. Haye: Chez Jean Neaulme.

REVISTA DO INSTITUTO DOS ADVOGADOS BRAZILEIROS. (1862-1893). Rio de Janeiro: Typ. de Quirino \& Irmão, trimestral.

REVISTA DOS TRIBUNAES: dos juizes e factos judiciais, do foro e da jurisprudencia. (1856-1859). Rio de Janeiro: Typ. Universal de Laemmert, duas vezes por mês.

\section{Referências bibliográficas:}

Alencar, José de. (1977). Discursos Parlamentares de José de Alencar_DeputadoGeral pela província do Ceará (1861-1877), Brasília: Câmara dos Deputados.

Bauman, Zygmunt. (1999). Globalização, Rio de Janeiro: Jorge Zahar Ed. . (1998). O Mal-Estar da Pós Modernidade, Rio de Janeiro: Jorge Zahar Ed. (2001). Modernidade Líquida, Rio de Janeiro: Jorge Zahar Ed.

Benchimol, Jaime Larry. (1992). Pereira Passos: um Haussmann Tropical, Rio de Janeiro: Biblioteca Carioca.

Bernardes, Denis Antônio de Mendonça. (2006). O Patriotismo Constituicional: Pernambuco, 1820-1822, São Paulo-Recife: Editora Universitária.

Birman, Joel. (2001). Mal-estar na atualidade, Rio de Janeiro: Civilização Brasileira.

Canguilhem, Georges. (1990). O Normal e o Patológico, Rio de Janeiro: Forense Universitária. 
Chorão, Luís Bigotte. (2002). O Periodismo Jurídico Português do Século XIX Páginas de História da Cultura Nacional Oitocentista, Lisboa: Imprensa Nacional/Casa da Moeda.

Contier, Arnaldo Daraya. (1979). Imprensa e Ideologia em São Paulo, 1822-1842: matizes do vocabulário político e social, Petrópolis: Vozes.

Costa, Jurandir Freire. (1989). Ordem Médica e Norma Familiar, Rio de Janeiro: Edições Graal.

Faoro, Raymundo. (2001). Os Donos do Poder: formação do patronato político brasileiro, São Paulo: Globo.

Ferreira, Antônio Celso (Org.). (2007). O Historiador e seu Tempo. Unesp, São Paulo.

Formiga, Armando Soares de Castro. "O Periodismo Jurídico em Portugal e no Brasil do Século XIX", disponível em www.geocities.com/armandoformigal, acesso em 24.9.2008.

Foucault, Michel. (1979). Microfísica do Poder, Rio de Janeiro: Edições Graal. . (2001). Os Anormais, São Paulo: Martins Fontes.

. (1993). Vigiar e Punir: história da violência nas prisões, Petrópolis: Vozes.

Freud, Sigmund. (1974). O Mal-estar na Civilização. Coleção Obras Completas, Rio de Janeiro: Imago Editora Ltda.

Giddens, Antony. (1991). As Conseqüências da Modernidade, São Paulo: Unesp.

Grinberg, Keila. (2002). O Fiador dos Brasileiros, Rio de Janeiro: Civilização Brasileira. 
(2002). Código Civil e Cidadania, Rio de Janeiro: Jorge Zahar Editor.

Guattari, Felix; Rolnik, Sueli. (1986). Micropolítica: Cartografias do Desejo, Petrópolis: Editora Vozes Ltda.

Koselleck, Reinhart. (2006). Futuro Passado: contribuição à semântica dos tempos históricos, Rio de Janeiro: Contraponto: Ed. PUC-Rio.

Lustosa, Isabel. (2000). Insultos Impressos: a guerra dos jornalistas na Independência (1821-1823), São Paulo: Companhia das Letras.

Marson, Isabel Andrade. (1980). Movimento Praieiro: imprensa, ideologia e poder político, São Paulo: Ed. Moderna.

Meira, Sílvio. (1983). Teixeira de Freitas. O Jurisconsulto do Império, Vida e Obra. $2^{\underline{a}}$ ed, Brasília: Cegraf.

Neder, Gizlene. (2007). Iluminismo Jurídico-Penal Luso-Brasileiro: obediência e submissão, Rio de Janeiro: Revan.

. (1995). Discurso Jurídico e Ordem Burguesa no Brasil, Porto Alegre: Sergio Antonio Fabris Ed.

Neder, Gizlene e Cerqueira Filho, Gisálio. (2001). Idéias Jurídicas e Autoridade na Família, Rio de Janeiro: Ed. Revan.

Peixoto, Antônio Carlos et al. (2001). O Liberalismo no Brasil Imperial, Rio de Janeiro: Revan/UERJ.

Pena, Eduardo Spiller. (2005). Pajens da Casa Imperial, Campinas: Editora Unicamp. 
Schwarcz, Lilia Moritz. (2005). O Espetáculo das Raças: Cientistas, Instituições e a Questão Racial no Brasil 1870-1930, São Paulo: Companhia das Letras.

Sodré, Nelson Werneck. (1966). A História da Imprensa no Brasil, Rio de Janeiro: Civilização Brasileira.

Viana, Luiz Verneck et. al. (1999). A Judicialização da Política e das Relações Sociais no Brasil, Rio de Janeiro: Revan.

\section{O DIREITO}

R2

Conselheiro D. Francisco Bal \} Conselheiro Antonio Joaquim thazar da Silveira, Ministro Rabas, Lente jubilado de Di. do Supr. Trib. de Justiça. reito Civil Patrio, encarr Conselheiro Tristão de Alencar gado da consolidação da Araripe, Desembargador da leis do processo civil. Relação da Côrte, encarre- Conselheiro Joaquim Saldanh gado da consolidaçao das
leis do processo criminal, $\begin{gathered}\text { Conselheiro Joaquim Saldanhat } \\ \text { Marinho, Advogado do Col- }\end{gathered}$ selho de Estado.

Conselheiro Olegario Herculano

d'Aquinoe Castro, Desembar- Joāo José do Monte, Adrogador da Relação da Côrte. gado.

ESCRIPTORIO DA REDACCĀO

22 RUA NOVA DO OUVIDOR 22

$$
\text { oxase }
$$

RIO DE JANEIRO

TYP. DO-DIREIT0-, RUA NOVA DO OUVIDOR N. 22 